\author{
UNIVERSIDADE DE SÃO PAULO \\ FACULDADE DE ODONTOLOGIA DE BAURU
}

Rubens Pimenta Maciel

Efeitos da Inibição da Enzima Conversora de Angiotensina Sobre a Doença Periodontal Induzida Experimentalmente em Ratos 



\title{
Efeitos da Inibição da Enzima Conversora de Angiotensina Sobre a Doença Periodontal Induzida Experimentalmente em Ratos
}

\section{Rubens Pimenta Maciel}

\begin{abstract}
Dissertação apresentada à Faculdade de Odontologia de Bauru da Universidade de São Paulo, como parte dos requisitos para a obtenção do título de Mestre em Ciências, no Programa de Pós-graduação em Ciências Odontológicas Aplicadas, área de concentração em Biologia Oral

Orientador: Prof. Dr. Carlos Ferreira dos Santos
\end{abstract}

Versão corrigida 


\begin{tabular}{|l} 
Maciel, Rubens Pimenta \\
M187e Efeitos da Inibição da Enzima Conversora de \\
Angiotensina Sobre a Doença Periodontal Induzida \\
Experimentalmente em Ratos/ Rubens Pimenta Maciel. - \\
Bauru,2013 \\
$87 p$. :Il.; $30 \mathrm{~cm}$ \\
Dissertação (Mestrado) - Faculdade de Odontologia \\
de Bauru. Universidade de São Paulo. \\
Orientador: Prof. Dr. Carlos Ferreira dos Santos
\end{tabular}

\section{Nota}

A Versão original desta dissertação encontra-se disponível no serviço de Biblioteca da Faculdade de Odontologia de Bauru FOB-USP.

Autorizo, exclusivamente para fins acadêmicos e científicos, a reprodução total ou parcial desta dissertação, por processos fotocopiadores e outros meios eletrônicos.

Assinatura:

Bauru, 23 de outubro de 2013

Projeto de Pesquisa aprovado pelo Comitê de Ética em pesquisa da Faculdade de Odontologia de Bauru, Universidade de São Paulo.

Proc.no 013/2011

Bauru, 28 de junho de 2011 


\section{AGRADECIMENTOS}

A Deus por me proporcionar tudo e todos que fazem parte da minha vida.

Aos meus pais Paulo Sergio Goes Maciel e Maria José dos Reis Pimenta Maciel, pois através do exemplo, carinho e dedicação sempre me ensinaram a superar as adversidades e a formar o caráter de um filho que os admira,respeita e os ama muito.

A minha irmã Lais Pimenta Maciel, por ser uma pessoa batalhadora com um coração imenso e que será uma extraordinária mãe do meu sobrinho Artur (seja bem vindo).

A minha noiva Professora Doutora Carla Renata Sipert, por ser companheira, batalhadora, gentil e acima de tudo uma pessoa com um enorme coração do qual eu me orgulho todos os dias em estar ao seu lado.

A Família Sipert por me acolher com carinho e respeito.

Aos meus avós paternos João de Goes Maciel e Teresa Minetto Maciel, que sempre demonstraram que ninguém envelhece, apenas torna-se mais sábio a cada dia.

Aos meus avós maternos José Francisco Pimenta e Antônia Candida Pimenta, pois sempre me demonstraram que as pessoas mais simples geralmente são as mais sábias e também as mais corajosas.

Ao Grande Mestre Professor Doutor Carlos Ferreira dos Santos do qual me recebeu de braços abertos e que promoveu o meu crescimento acadêmico, acreditando e auxiliando em todos os momentos, além de demonstrar através do exemplo e dedicação que a ciência e a família merecem todo o sacrifício e dedicação e assim me sinto orgulhoso em participar dessa "família" do qual fui inserido do Departamento de Farmacologia da FOB/USP. 

Ao Professor Doutor Flávio Augusto Cardoso de Faria, pelos ensinamentos farmacológicos e também pelos ensinamentos e esclarecimentos espirituais para uma melhor compreensão ou explicação para nossas vidas.

Ao meu grande amigo e irmão Thiago José Dionísio que sempre me auxiliou academicamente ensinando e demonstrando todo o conhecimento que a ciência exige, além de ser um amigo desde as épocas de karate na academia bela vista, passando pelo ensino médio e auxiliando no ensino superior, muito obrigado por tudo irmão.

A secretária Vera Rufino por ser uma das pessoas mais fortes e dispostas que eu conheço afim de sempre auxiliar e tornar nossos dias mais agradáveis com sua presença.

\section{A Professora Dra Thais Marchini de Oliveira e Dra Bella Luna Colombini} Ishikiriama pelo auxílio para com a elaboração deste trabalho.

A técnica de laboratório Viviane Aparecida Parisi Santos, por estar sempre disposta a auxiliar nos trabalhos acadêmicos e tenho certeza que será uma ótima colega de profissão ao graduar se em Biologia, meu muito obrigado por tudo.

A todos os discentes e amigos Paulo Zupelari (Russo), Thaisinha, Adriana Calvo dentre outros por tornar o ambiente acadêmico uma ambiente excepcional de trabalho.

Ao CNPQ por apoiar esse projeto, cujo não seria possível este trabalho.

A todos da minha família que sempre me auxiliaram, estimularam e torceram para que eu seguisse com os estudos.

Esse trabalho é dedicado a meu primo Rafael Albuquerque, cujo foi à pessoa mais extraordinária e batalhadora que eu conheci e que deixou um enorme exemplo para toda a família. 



\section{RESUMO}

A doença periodontal (DP) compreende um grupo de lesões que afetam os tecidos periodontais de proteção (gengivite) e suporte (periodondite), envolvendo a participação de células residentes, células estruturais e mediadores inflamatórios. Pesquisas recentes mostram a existência de um Sistema Renina Angiotensina (SRA) local no tecido gengival de ratos e sugeriram que o SRA está envolvido na iniciação da progressão da DP induzida experimentalmente em ratos. Portanto, o objetivo deste trabalho foi avaliar se o enalapril, inibidor da enzima conversora de angiotensina (ECA), reduz a perda óssea e a expressão de componentes do SRA no tecido gengival. Para tanto foi utilizado o modelo de indução da DP por colocação de ligadura ao redor do primeiro molar inferior de ratos e tratamento destes animais com enalapril (20 mg/kg/dia, gavage), sendo utilizado micro CT para análise do volume ósseo. Os grupos experimentais foram os seguintes $(n=5)$ : Grupo 1 - prétratamento com enalapril por 14 dias, indução da DP e pós-tratamento por 14 dias; Grupo 2 - pré-tratamento com enalapril por 14 dias, indução da DP e póstratamento por 7 dias; Grupo 3 - pré-tratamento com enalapril por 7 dias, indução da DP e pós-tratamento por 14 dias; Grupo 4 - pré-tratamento com enalapril por 7 dias, indução da DP e pós-tratamento por 7 dias. Para fins de comparação, em todos os grupos, além do tratamento com enalapril, outros animais receberam água $(n=5)$ e em outros $(n=5)$ foi realizada cirurgia fictícia para indução da DP (sham). Foram realizadas análises de perda óssea alveolar e reação em cadeia da polimerase quantitativa (qPCR) dos seguintes componentes do SRA como Angiotensinogênio (AGT), ECA, ECA-2 e dos receptores AT1a, AT1b, AT2 e Mas). Os dados foram devidamente analisados por meio de gráficos, sendo utilizado o teste t para comparação dos animais tratados com enalapril ou água com os respectivos sham, adotando-se o nível de significância de $5 \%$. Os resultados demonstraram que apenas no grupo com o menor tempo de pré-tratamento com o enalapril (Grupo 3) não houve bloqueio da perda óssea, porém nos demais grupos houve diminuição de forma estatisticamente significativa deste parâmetro (Grupos 1, 2 e 3). Em relação à análise molecular, de todos os alvos testados, apenas a expressão do AGT e receptor Mas foi alterada, com aumento estatisticamente significativo da expressão do RNAm para esta enzima identificado no grupo 4. Em conclusão, o pré-tratamento com enalapril, inibidor da ECA, pode prevenir a perda óssea alveolar no modelo de DP induzida experimentalmente em ratos.

Palavras-chave: Doença Periodontal, Sistema Renina-Angiotensina, Enalapril, Enzima Conversora de Angiotensina 



\section{ABSTRACT}

Periodontal disease (PD) comprises a group of injuries affecting the periodontal tissue protection (gingivitis) and support (periodondite), involving the participation of resident cells, structural cells and inflammatory mediators. Recent research has shown the existence of a Renin Angiotensin System (RAS) site in the gingival tissue of rats and suggested that the SRA is involved in the onset of progression of PD experimentally induced in rats. Therefore, the aim of this study was to evaluate whether enalapril, angiotensin converting enzyme (ACE), bone loss and reduces the expression of RAS components in the gingival tissue. For this model was used for induction of PD placement of ligature around the mandibular first molar of rats and treatment of these animals with enalapril ( $20 \mathrm{mg} / \mathrm{kg} /$ day gavage) being used for micro-CT analysis of bone volume. The experimental groups were as follows $(n=5$ each): Group 1 - the pre-enalapril treatment for 14 days, and DP induction of post-treatment for 14 days, Group 2 - the pre-enalapril treatment for 14 days, induction of DP and after treatment for 7 days and Group 3 - pre-enalapril treatment for 7 days, induction of PD-and post-treatment for 14 days, and Group 4 - the preenalapril treatment for 7 days, induction of post-treatment DP, and for 7 days. For comparison, all groups, and treatment with enalapril other animals received water ( $\mathrm{n}$ $=5)$ and other $(n=5)$, sham surgery was performed to induce PD (sham). Analyses of alveolar bone loss and polymerase chain reaction quantitative (qPCR) of the following RAS components (angiotensinogen, ACE, ACE-2 receptor and AT1a, AT1b, AT2 and Mas). The data were properly analyzed by means of graphs, by using the $t$ test for comparison of animals treated with enalapril or water with their sham, adopting a significance level of $5 \%$. The results showed that only in the group with the shortest pre-treatment with enalapril (Group 3) showed no blocking of bone loss, but the other groups was statistically significant decrease in this parameter (Groups 1,2 and 3). Regarding the molecular analysis of all targets tested, only the expression of angiotensinogen and Mas receptor was altered, with a statistically significant increase in the expression of mRNA for this enzyme identified in group 4 . In conclusion, pre-treatment with enalapril ACE inhibitor can prevent bone loss in PD model experimentally induced in rats.

Keywords: Periodontal Disease, Renin-Angiotensin System, Enalapril, Angiotensin Converting Enzyme 



\section{LISTA DE FIGURAS}

Figura 1: Principais componentes do sistema renina angiotensina ......................16

Figura 2: Esquema referente à via alternativa para a produção de angiotensina II)

Figura 3: Representação dos componentes presentes no SRA, seus respectivos receptores além de suas respostas sistêmicas e moleculares

Figura 4: Ang II participa em importantes eventos da resposta inflamatória PG - prostaglandinas; VEGF - fator de crescimento endotelial vascular

Figura 5: Ação do enalapril inibindo a ação da enzima conversora de angiotensina na cascata do sistema renina angiotensina

Figura 6: Imagem representando a indução da doença periodontal no primeiro molar no rato. A: primeiro molar com o fio de sutura. B: primeiro molar após a retirada do fio de sutura.

Figura 7: Representação do volume ósseo feita por análise através da técnica de microtomografia . A: primeiro molar analisado através da técnica de microtomografia, onde é representada a estrutura óssea e o dente. B: representa apenas a estrutura óssea analisada referente ao volume ósseo em $\mathrm{mm}^{3}$.

Figura 8: Volume ósseo alveolar ao redor do primeiro molar de todos os grupos estudados de acordo com o tempo de pré e pós-tratamento analisados por microtomografia computadorizada. Grupo 1 = ratos pré-tratados por 14 dias com água ou enalapril, indução da DP no $14^{\circ}$ dia e pós-tratamento por 14 dias com água ou enalapril; Grupo 2 = ratos pré-tratados por 14 dias com água ou enalapril, indução da DP no $14^{\circ}$ dia e pós-tratamento por 7 dias com água ou enalapril; Grupo 3 = ratos prétratados por 7 dias com água ou enalapril, indução da DP no $7^{\circ}$ dia e pós-tratamento por 7 dias com água ou enalapril e Grupo 4 = ratos pré-tratados por 7 dias com água ou enalapril, indução da DP no $7^{0}$ dia e póstratamento por 14 dias com água ou enalapril. * vs Sham tratado com água $\mathrm{e}^{\#}$ vs DP tratado com água 

Figura 9: Representação da perda óssea do grupo pré-tratado com água ou enalapril durante 14 dias e pós-tratado com água ou enalapril durante 14 dias. Através da técnica de microCT. A: Grupo tratado com água sem a indução da doença periodontal. B: grupo tratado com água com a indução da doença periodontal. C: grupo tratado com enalapril sem a indução da doença peridontal. D: grupo tratado com enalapril com a indução da doença periodontal.

Figura 10: Representação gráfica da expressão do receptor de angiotensinogênio em relação ao GAPDH em amostras de animais sham e DP tratados com água ou enalapril, referente aos diferentes tempos de tratamento farmacológicos. SHAM: operação fictícia para a indução da doença periodontal . DP: doença periodontal induzida experimentalmente.

Figura 11: Representação gráfica da expressão do receptor da ECA em relação ao GAPDH em amostras de animais sham e DP tratados com água ou enalapril, referente aos diferentes tempos de tratamento farmacológicos. SHAM: operação fictícia para a indução da doença periodontal . DP: doença periodontal induzida experimentalmente. \# vs ratos com DP tratados com água

Figura 12: Representação gráfica da expressão do receptor da ECA-2 em relação ao GAPDH em amostras de animais sham e DP tratados com água ou enalapril, referente aos diferentes tempos de tratamento farmacológicos. SHAM: operação fictícia para a indução da doença periodontal . DP: doença periodontal induzida experimentalmente. \# vs ratos com DP tratados com água. \& vs ratos sham tratados com água

Figura 13: Representação gráfica da expressão do receptor da At1a em relação ao GAPDH em amostras de animais sham e DP tratados com água ou enalapril, referente aos diferentes tempos de tratamento farmacológicos. SHAM: operação fictícia para a indução da doença periodontal . DP: doença periodontal induzida experimentalmente. \# vs ratos com DP tratados com água. \& vs ratos sham tratados com água 

Figura 14: Representação gráfica da expressão do receptor da At1b em relação ao GAPDH em amostras de animais sham e DP tratados com água ou enalapril, referente aos diferentes tempos de tratamento farmacológicos. SHAM: operação fictícia para a indução da doença periodontal . DP: doença periodontal induzida experimentalmente

Figura 15: Representação gráfica da expressão do receptor da AT2 em relação ao GAPDH em amostras de animais sham e DP tratados com água ou enalapril, referente aos diferentes tempos de tratamento farmacológicos. SHAM: operação fictícia para a indução da doença periodontal . DP: doença periodontal induzida experimentalmente 58

Figura 16: Representação gráfica da expressão do receptor Mas em relação ao GAPDH em amostras de animais sham e DP tratados com água ou enalapril, referente aos diferentes tempos de tratamento farmacológicos. SHAM: operação fictícia para a indução da doença periodontal . DP: doença periodontal induzida experimentalmente. diferença estatisticamente significativa $(p<0,05)$ em relação ao respectivo grupo sham. \& vs ratos sham tratados com água 



\section{LISTA DE TABELAS}

Tabela 1 - Alvos da PCR quantitativa e códigos dos ensaios inventoriados (Applied Biosystems ${ }^{\circledR}$ ) utilizados nos

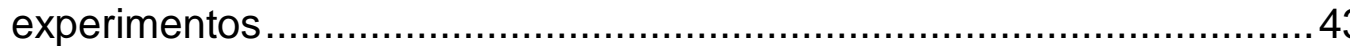





\section{LISTA DE ABREVIATURAS E SIGLAS}

AGT = angiotensinogênio

Ang 1-7 = angiotensina 1-7

Ang 1-9 = angiotensina 1-9

Ang $\mathrm{I}=$ angiotensina $\mathrm{I}$

Ang II = angiotensina II

AT1 $=$ receptor de angiotensina tipo 1

$A T 1_{a}=$ receptor de angiotensina tipo $1 \mathrm{a}$

$A T 1_{b}=$ receptor de angiotensina tipo $1 \mathrm{~b}$

AT2 = receptor de angiotensina tipo 2

$\mathrm{BRA}=$ bloqueadores de receptores de Angiotensina

$\mathrm{Ct}=$ cicle threshold ou ciclo limiar

DP = Doença Periodontal

$E C A=$ Enzima Conversora de Angiotensina

ECA-2 = Enzima Conversora de Angiotensina-2

et al. $=$ e colaboradores

FOB/USP = Faculdade de Odontologia de Bauru/ Universidade de São Paulo

IFN- $\gamma=$ interferon gama

$\mathrm{IL}-1 \beta=$ interleucina 1 beta

IL-6 = interleucina 6

LOX-1 (receptor 1 tipo lectina de lipoproteína de baixa densidade)

Mas $=$ receptor Mas

$\mu \mathrm{l}=$ microlitros

$\mathrm{mL}=$ mililitros

$\mathrm{mm}=$ milímetros

$\mathrm{nm}=$ nanômetros

$\mathrm{NAD}(\mathrm{P}) \mathrm{H})$ nicotinamida adenina dinucleotídeo fosfato oxidase

$\mathrm{NO}=$ óxido nítrico

$P G=$ prostaglandinas

PGE2 = prostaglandina $E_{2}$

qPCR = reação de cadeia de polimerase quantitativo 

$\mathrm{RNA}_{\mathrm{m}}=\mathrm{RNA}$ mensageiro

RANK = receptor ativador de NF-KB

RANKL = ligante do receptor ativador de NF-KB

$\mathrm{RT}=$ transcrição reversa

RT PCR = transcrição reversa seguida de reação em cadeia de polimerase

SHAM = grupo controle tratado com água

$\mathrm{SNC}=$ sistema nervoso central

$\mathrm{SRA}=$ Sistema Renina Angiotensina

TNF- $\alpha=$ fator de necrose tumoral alfa

VEGF = fator de crescimento endotelial vascular

7-DP-7 = 7 dias de pré tratamento ; indução da doença periodontal ; 7 dias de pós tratamento

7-DP-14 = 7 dias de pré tratamento ; indução da doença periodontal ; 14 dias de pós tratamento

14-DP-7 = 14 dias de pré tratamento ; indução da doença periodontal ; 7 dias de pós tratamento

14-DP-14 = 7 dias de pré tratamento ; indução da doença periodontal ; 7 dias de pós tratamento 



\section{SUMÁRIO}

1 INTRODUÇÃO e SÍNTESE BIBLIOGRÁFICA ….......................................13

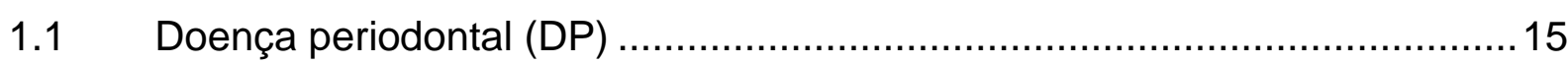

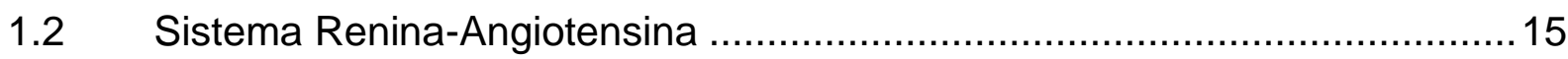

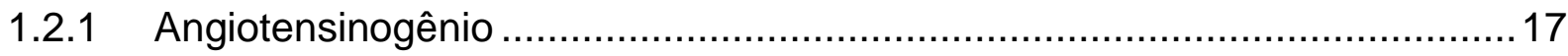

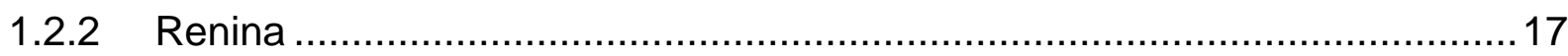

1.2.3 Enzima Conversora De Angiotensina (ECA) …........................................ 18

1.2.4 Enzima Conversora De Angiotensina-2 (Eca-2) ...................................18

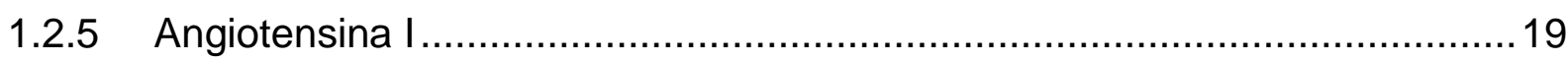

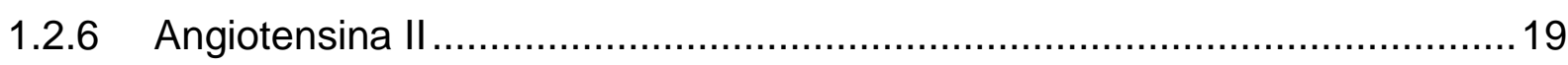

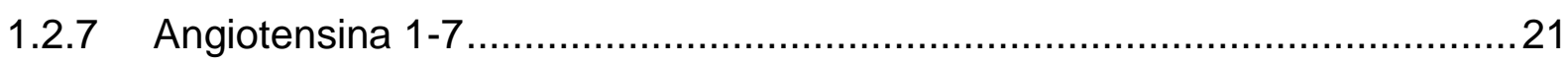

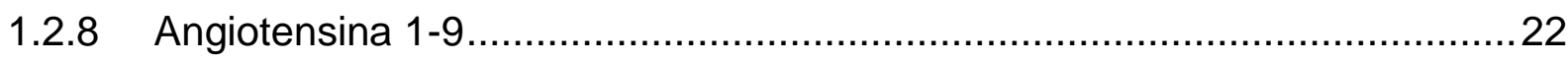

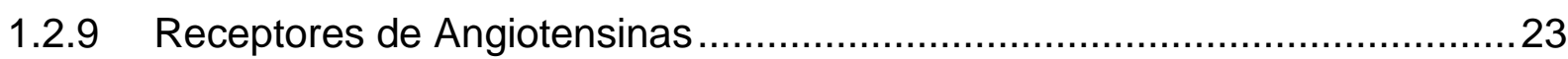

1.3 Vias alternativas da geração de angiotensina II .......................................24

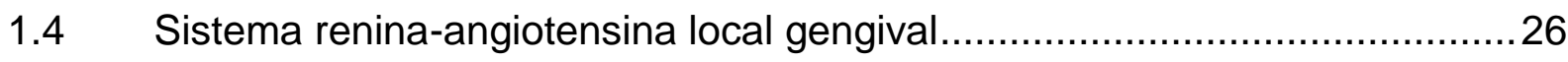

1.5 Interação entre Inflamação e Angiotensina II ...............................................28

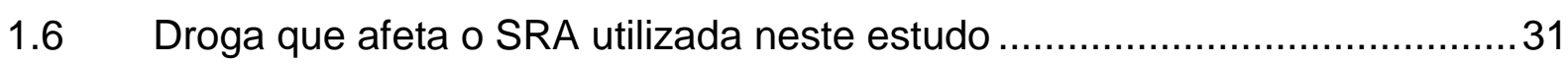

1.7 Modelos animais para estudo da doença periodontal................................. 32

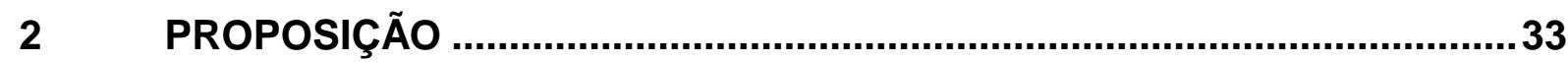

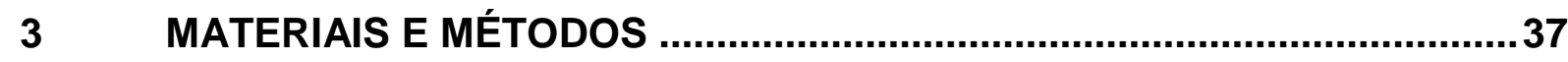

3.1 Animais e caracterização dos grupos experimentais .....................................39

3.2 Doença Periodontal induzida experimentalmente em ratos......................... 40

3.3 Obtenção de espécimes para os diferentes experimentos ...........................41

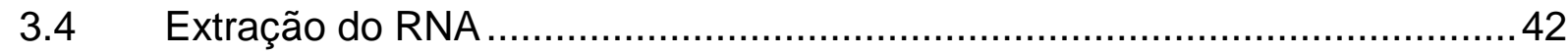

3.4.1 Quantificação e qualificação do RNA ………......................................... 42

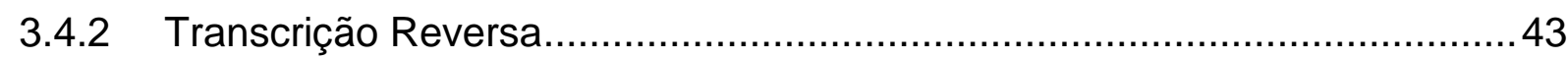

3.4.3 Reação em cadeia da polimerase quantitativa (qPCR) .............................43

3.5 Análise do Volume ósseo por microtomografia ......................................... 44

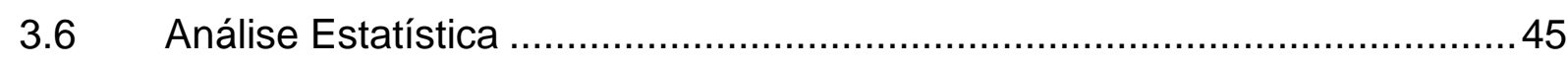





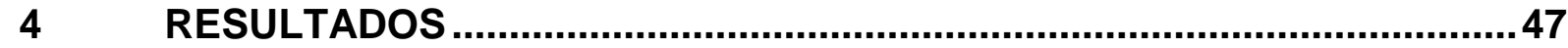

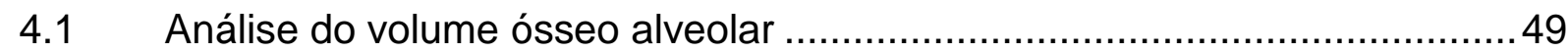

4.2 Análise do Volume ósseo por Microtomografia computadorizada .50

4.3 Análise da expressão gênica no tecido gengival de todos os componentes do Sistema Renina-Angiotensina ........................................52

4.3.1 Análise da expressão do RNAm para Angiotensinogênio ...........................53

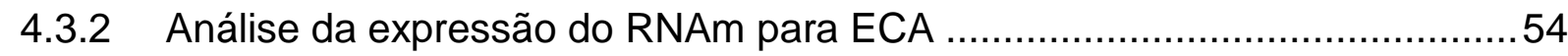

4.3.3 Análise da expressão do RNAm para ECA-2 …........................................55

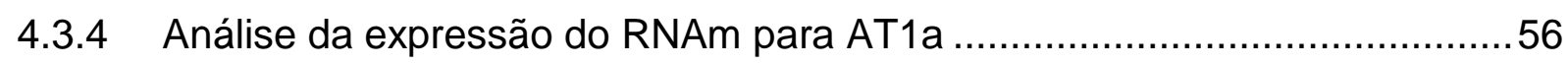

4.3.5 Análise da expressão do RNAm para AT1b ..........................................57

4.3.6 Análise da expressão do RNAm para AT2 …...........................................58

4.3.7 Análise da expressão do RNAm para Receptor Mas..................................59

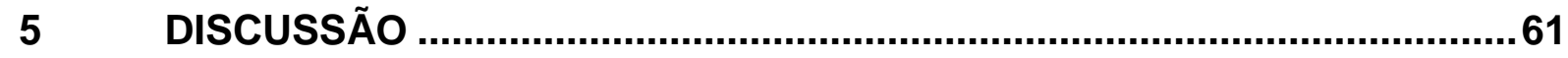

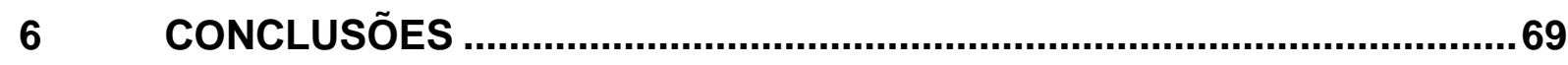

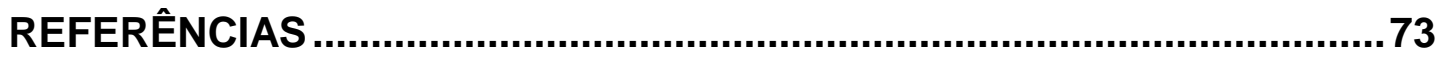

ANEXO 



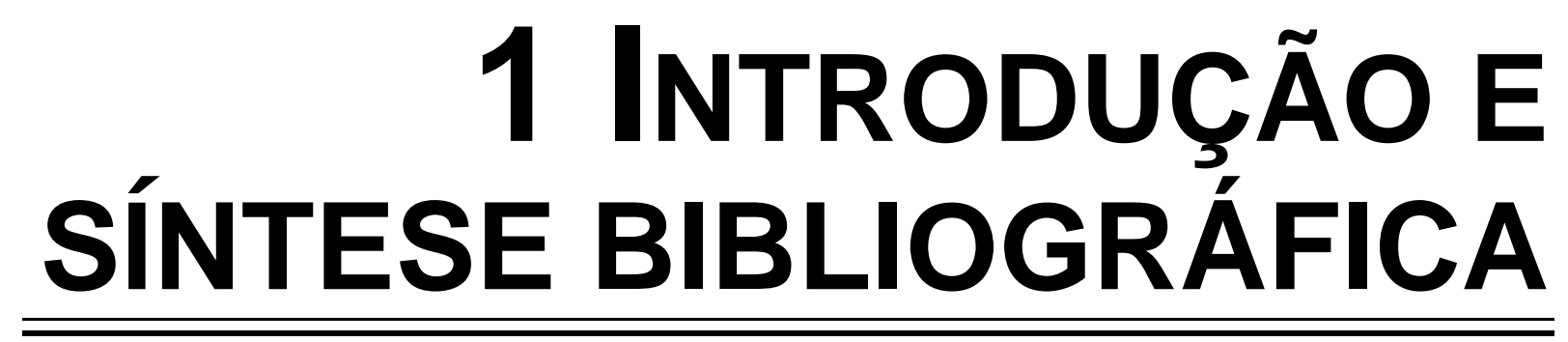





\section{INTRODUÇÃO E SÍNTESE BIBLIOGRÁFICA}

\subsection{DOENÇA PERIODONTAL (DP)}

Entre os processos patológicos que afetam a dentição humana, as doenças periodontais são das mais comumente observadas. É bem documentado que de $5 \%$ a $15 \%$ de qualquer população sofre de periodontite generalizada, apesar da periodontite moderada afetar em maior número os adultos (Oliver, 1998; Burt, 2005).

Essas doenças compreendem um grupo de lesões que afetam os tecidos periodontais de proteção (gengiva), denominando-se gengivite, e de suporte (cemento, osso alveolar e ligamento periodontal), denominando-se periodontite, a qual pode levar à perda dentária (Flemmig, 1999).

A principal causa da doença periodontal é a placa dentobacteriana que se acumula sobre a superfície dentária, bem como ao nível e abaixo da margem da gengiva. Este acúmulo causa inflamação e fibrose da gengiva, levando à destruição do ligamento periodontal e do osso alveolar. Com a progressão da doença, os tecidos moles separam-se da superfície dentária resultando na lesão característica da periodontite crônica - a bolsa periodontal (Wilson, 1995; Van Dyke e Serhan, 2003).

Interações entre patógenos microbianos e vários sistemas de resposta do hospedeiro desempenham um papel crítico no desenvolvimento e progressão da DP via liberação de vários mediadores inflamatórios e imunológicos (Page, 1991; Ebersole, 2003).

\subsection{SISTEMA RENINA-ANGIOTENSINA (SRA)}

O sistema renina-angiotensina (SRA) circulante é um sistema endócrino que promove a liberação de angiotensina (Ang) II, a qual exerce seus efeitos pela interação com receptores específicos (Peach, 1977; Leung, 2004; Paul; Mehr; Kreutz, 2006). A Ang II é gerada pela ação da renina, uma enzima produzida pelos rins, sobre o angiotensinogênio (AGT) plasmático, produzido pelo fígado, formando o 
decapeptídeo Ang I (Asp ${ }^{1}-\mathrm{Arg}^{2}-\mathrm{Val}^{3}-\mathrm{Tyr}^{4}-\mathrm{Ile}^{5}-\mathrm{His}^{6}-\mathrm{Pro}^{7}-\mathrm{Phe}^{8}-\mathrm{His}^{9}-\mathrm{Leu}^{10}$ ), que é clivado na ligação $\mathrm{Phe}^{8}-\mathrm{His}^{9}$ pela enzima conversora de Ang I, presente em abundância no endotélio pulmonar, liberando o octapeptídeo ativo Ang II (Asp ${ }^{1}-\mathrm{Arg}^{2}$ $\mathrm{Val}^{3}-\mathrm{Tyr}^{4}-\mathrm{Ile}^{5}-\mathrm{His}^{6}-\mathrm{Pro}^{7}-\mathrm{Phe}^{8}$ ). A Figura 1 ilustra o SRA com os componentes descritos acima, além de outros que serão apresentados a seguir.

\section{Angiotensinogênio}

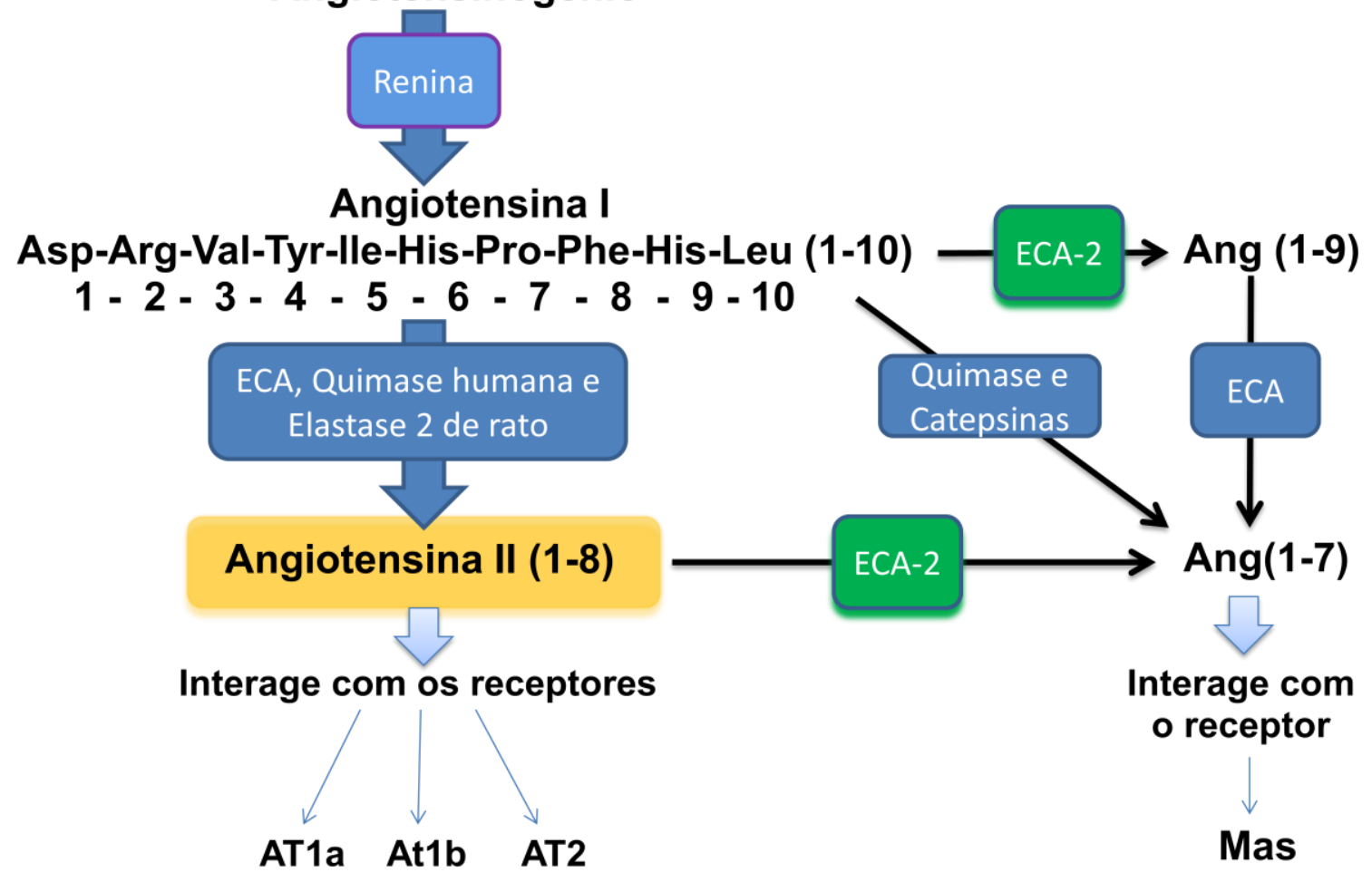

Figura 1 - Principais componentes do sistema renina-angiotensina.

A clássica visão referente ao SRA é de que este é um sistema endócrino, porém atualmente essa visão vem sendo modificada e de um modo mais atual, esse sistema inclui também a presença dos SRA locais (teciduais), pois estes também são considerados produtores de Ang II. Essa constatação foi confirmada graças ao seu papel em vários processos como a inflamação, hipertrofia e osteoporose. (Goodman e Gilman, 2012). 


\subsubsection{Angiotensinogênio (AGT)}

O AGT humano, uma enzima alfa 2 globulina de 452 aminoácidos, é sintetizado no fígado. O RNAm que codifica a proteína também é abundante no tecido gorduroso, em determinadas regiões do Sistema Nervoso Central (SNC) e nos rins (Campbell; Habener, 1986; Cassis; Save; Peach, 1988). Vários hormônios como glicocorticóides, hormônio tireoidiano e a própria Ang II (Bem-Ari; Garrison, 1988) estimulam a síntese de AGT.

O AGT pode ser convertido em Angiotensina I ou diretamente em Angiotensina II através da catepsina G e Tonina, esta via é considerada como uma via alternativa para a produção destes substratos. (Paul e Cols., 2006).

Pesquisas apontam que a superexpressão de angiotensinogênio induz a inflamação no tecido adiposo (Nishan S., 2012).

\subsubsection{Renina}

A enzima renina é uma glicoproteína de 340 aminoácidos, sendo sintetizada e armazenada sob a forma inativa, denominada pró-renina nas células justaglomerulares dos rins, que são células musculares lisas modificadas localizadas nas paredes das arteríolas aferentes (Oliveira, $M$ et al. 1999).

Com a queda de pressão arterial, reações intrínsecas nos próprios rins fazem com que muitas moléculas de pró-renina sejam clivadas assim liberando a renina. A secreção da renina é controlada por 3 mecanismos: 2 agem predominantemente nos rins (mecanismo de mácula densa e mecanismo barorreceptor infra-renal) e o $3^{\circ}$ age por meio do SNC (mecanismo do receptor $\beta$-adrenérgico). O mecanismo denominado de feedback negativo de alça curta consiste no fato de que elevações da secreção de renina aumentam a formação de Ang II, que, interagindo com seus receptores renais, inibe a liberação de renina nas células justaglomerulares. O mecanismo de feedback negativo de alça longa consiste na inibição da liberação da renina devido a aumentos da pressão arterial induzidos pela Ang II (Jackson; Garrison, 1995).

Dados apontam que a pró-renina que anteriormente era considerado um "precursor inativo" tem uma grande atuação em ativar o SRA local (tecidual) relacionado também com eventos dependentes ou não da angiotensina II e visto que 
as concentrações de pró-renina citoplasmáticas em pacientes diabéticos podem chegar a concentrações de 100 vezes maiores do que em relação a um paciente saudável e que devido a isso, podem estar envolvidas em um maior aumento dos processos que afetam os rins e suas respectivas estruturas (Danser e Deinum, 2005 ; Nguyen e Danser, 2008).

\subsubsection{Enzima Conversora De Angiotensina (ECA)}

A enzima conversora de angiotensina humana, uma metaloprotease de ligação de membrana, contém 1.278 resíduos de aminoácidos e possui 2 domínios homólogos, cada um com um local catalítico e com uma região de ligação do zinco (Soubrie et al., 1988; Berstein et al., 1989). A ECA é encontrada abundantemente no endotélio dos vasos pulmonares (Ryan et al., 1975, 1976) e também no plasma e em diversos tecidos orgânicos como endotélio vascular (Caldwell et al., 1976; Ryan et al., 1976), cérebro, placenta, intestino e nos túbulos renais (Hall et al., 1976; Erdös ; Skidgel , 1986; Schulz et al., 1988).

\subsubsection{Enzima Conversora De Angiotensina-2 (Eca-2)}

A ECA-2 tem sido descrita como uma metaloprotease dependente de zinco com atividade de carboxipeptidase. A ECA-2 está envolvida na geração de peptídeos de angiotensina alternativos, em particular pela conversão de Ang II em Ang 1-7, sendo esta considerada sua principal função, e Ang I em Ang 1-9. A expressão de genes da ECA-2 é descrita no sistema cardiovascular, no córtex renal e medula, em alguns tecidos do trato gastrintestinal, nos testículos (Raizada; Ferreira, 2007), endotélio vascular, hipotálamo e na parede da aorta (Fyhrquist, F; Saijonmaa, O.;2008; Santos R,A. Ferreira A,J.;2007). A ECA-2 também está presente em macrófagos, células endoteliais e musculares lisas (Kramkowski; Mogielnicki; Buczko, 2006) e tem sido sugerida como um importante regulador das funções cardíacas e do desenvolvimento (Paul; Mehr; Kreutz, 2006).

Porém a regulação referente a ECA-2 ainda não foi totalmente elucidada, sendo assim sua regulação ainda não foi constatada como completa, nem pelos inibidores da ECA e nem pelos da BRA (Bloqueadores de receptores de Angiotensina), porém ambos apresentam uma certa auto-regulação na expressão da 
ECA-2 relacionados ao córtex renal e no miocárdio de ratos. (Ferrario CM.; 2006).

Contudo dados apontam que a expressão da ECA-2 no coração, contribue para um aumento do infarto do miocárdio. (Burrell LM, Risvanis J, Kubota E et al.; 2005).

Atualmente nota se que a ECA-2 não é inibida pelos inibidores padrões da ECA e que o mesmo não tem efeito sobre a bradicinina. (Goodman e Gilman, 2012).

\subsubsection{Angiotensina I}

A angiotensina I é um peptídeo de 10 aminoácidos (Asp ${ }^{1}-\mathrm{Arg}^{2}-\mathrm{Val}^{3}-\mathrm{Tyr}^{4}-1 \mathrm{e}^{5}$ $\mathrm{His}^{6}-\mathrm{Pro}^{7}-\mathrm{Phe}^{8}$-His ${ }^{9}$-Leu ${ }^{10}$ ) desprovido de propriedades vasoconstritoras capazes de produzir em alterações funcionais significativas na função circulatória; serve como substrato para vias enzimáticas formadoras de Ang II (Paul; Mehr; Kreutz, 2006).

Ao bloquear a cascata do SRA, a angiotensina I é acumulada e consequentemente é desviada para as vias metabólicas alternativas, resultando assim na produção aumentada de certos peptídeos como a angiotensina 1-7 (Goodman e Gilman, 2012).

\subsubsection{Angiotensina II}

Pela ação da ECA, há a liberação dos 2 últimos aminoácidos da Ang I $\left(\mathrm{His}^{9}\right.$ Leu $^{10}$ ), formando a Ang II, um octapeptídeo (Asp $\left.{ }^{1}-\mathrm{Arg}^{2}-\mathrm{Val}^{3}-\mathrm{Tyr}^{4}-\| \mathrm{e}^{5}-\mathrm{His}^{6}-\mathrm{Pro}^{7}-\mathrm{Phe}^{8}\right)$. A Ang II é considerada o principal peptídeo efetor do SRA (Paul; Mehr; Kreutz, 2006).

Além do seu efeito vasoconstritor e estimulatório sobre a secreção de aldosterona, a Ang II tem uma ação ionotrópica e cronotrópica positiva sobre o coração (Peach, 1977). Em adição aos seus efeitos no sistema cardiovascular, temse demonstrado que a Ang II está envolvida em outras funções, tais como mitogênese de fibroblastos da pele, síntese de DNA por células do ligamento periodontal, regulação da formação óssea, crescimento celular, apoptose, geração de espécies reativas ao oxigênio, secreção hormonal, ações pró-fibrogenéticas, tônus vascular e indução da liberação de prostaglandina $E_{2}\left(P E_{2}\right)$ em fibroblastos gengivais humanos (Nickenig et al., 1997; lundergan et al., 1999; Hiruma et al., 1997; 
Hagiwara et al., 1998; Lamparter et al., 1998; Segawa et al , 2003; Paul; Mehr; Kreutz, 2006).

Vários estudos têm mostrado a participação de outras enzimas, além da ECA, na geração de Ang II. As primeiras descrições de uma via alternativa de formação da Ang II foram relatadas por Boucher, Asselin e Genest (1974) nas glândulas submandibulares de rato, por Cornish, Joyner e Gilmore (1979) na bochecha de hamster e no músculo papilar cardíaco de gato. Cornish, Joyner e Gilmore (1979) também observaram a formação de Ang II de forma independente da ECA na artéria coronária de hamster. Okunishi, Miyazaki e Toda (1984) identificaram uma enzima geradora de Ang II sensível à quimostatina na artéria mesentérica de cão, a qual também é insensível a inibidores da ECA (como por exemplo o captopril). Urata et al. (1990) demonstraram in vitro um duplo caminho para a formação de Ang II em homogenatos de coração humano. Esses autores observaram que aproximadamente $80 \%$ da formação total de Ang II associava-se à presença de uma serino-protease até então desconhecida, enquanto a atividade formadora de Ang II dependente da ação da ECA era responsável somente por aproximadamente $11 \%$ da formação total de Ang II. Esta serino-protease cardíaca foi posteriormente purificada e identificada como um novo membro da família quimase e, desde então, denominada de quimase do coração humano (Urata et al., 1990).

Embora várias enzimas, incluindo a tripsina, quimotripsina, tonina, catepsina G, calicreína e quimase I de rato, possam produzir Ang II in vitro por meio da clivagem da ligação Phe ${ }^{8}-\mathrm{His}^{9}$ da Ang I (Urata; Nishimura; Ganten, 1995; Hollenberg; Fisher; Price, 1998), a atividade fisiológica das mesmas no sistema cardiovascular in vivo não está esclarecida. Além disso, algumas destas enzimas, como por exemplo tripsina e quimotripsina, também degradam a Ang II (Le Trong; Neurath; Woodbury, 1987), deixando em dúvida a função destas enzimas na formação deste hormônio. Interessante notar que, enquanto as quimases humana e de hamster clivam eficientemente Ang I, formando Ang II (Takal et al., 1996; Urata et al., 1990), a quimase I de rato apresenta principalmente atividade de degradação da Ang II (Le Trong; Neurath; Woodbury, 1987). Dados gerados a partir da suscetibilidade dessas diferentes enzimas a inibidores de proteases permitiram a classificação das enzimas formadoras de Ang II em três categorias (Arakawa, 1996). A primeira categoria corresponde à metalodipeptidil carboxipeptidase conhecida como ECA. A segunda categoria inclui um grupo de serino-proteases sensíveis à quimostatina, tais como a 
enzima geradora de Ang II sensível à quimostatina da artéria mesentérica de cão (Okunishi et al., 1987), quimase (Urata et al., 1990b; Takai et al., 1996), catepsina G (Tonnesen et al., 1982) e elastase-2 (Paula et al., 1998; Santos C et al., 2002a; Santos C et al., 2002b; Santos C et al.; 2003; Santos C et al., 2004). A terceira categoria agrupa as serino-proteases sensíveis à aprotinina, destacando-se a calicreína (Maruta; Arakawa, 1983), tripsina (Arakawa, 1996) e tonina (Boucher; Asselin; Genest, 1974).

Além disso, pesquisas apontam que a angiotensina II tem uma papel modulador importante em algumas enfermidades como a doença pulmonar aguda e na inflamação (Hagiwara,S. et al. 2009).

A Ang II parece estar bastante envolvida durante o processo inflamatório, pois seus mediadores secundários, tais como prostaglandinas e fator de crescimento vascular endotelial (VEGF) influenciam na permeabilidade vascular (Suzuki et al.2003) e na migração e adesão de leucócitos (Piqueras et al. 2000). A adesão dos leucócitos foi atenuada pelo anticorpo anti-P-selectina e com a terapia da combinação dos antagonistas dos receptores AT1 e AT2, sugerindo que ambos os receptores participam no processo de adesão dos leucócitos.

Além das ações supracitadas, a Ang II participa da diferenciação das células derivadas da medula óssea tais como macrófagos e células dendríticas (Lapteva et. al 2001). Tem sido relatado ainda que a ligação da Ang II ao receptor AT1 nos osteoblastos aumenta a expressão de RANKL (ligante do receptor ativador de NFKB) o qual se liga aos receptores RANK (receptor ativador de NF-KB) nos osteoclastos aumentando a reabsorção óssea (Shimizu et al. 2008).

\subsubsection{Angiotensina 1-7}

A angiotensina 1-7 é um componente bioativo do SRA, sendo um heptapeptídeo (Asp ${ }^{1}-\mathrm{Arg}^{2}-\mathrm{Val}^{3}-\mathrm{Tyr}^{4}-\mathrm{Ile}^{5}-\mathrm{His}^{6}-\mathrm{Pro}^{7}$ ) amino-terminal formado a partir da Ang I por ação de endopeptidases neutras, ou seja, por uma via independente da ECA (Santos, R et al., 1988; Santos; Compagnole-Santos, 1994). Algumas destas enzimas como a neprilisina estão envolvidas no metabolismo do fator natriurético atrial e bradicinina. A ECA também tem sido envolvida no metabolismo e quebra da Ang 1-7, sugerindo uma interação entre diferentes sistemas de peptídeos cardiovasculares (Paul; Mehr; Kreutz, 2006). A Ang 1-7 tem ações contra- 
regulatórias com a Ang II, como a proliferação celular da Ang II e ações antiproliferativas da Ang 1-7. Enquanto a Ang II tem efeitos vasoconstritores, a Ang 1-7 tem efeitos vasodilatadores. A Ang 1-7 pode regular a pressão sanguínea, a função cardíaca e o crescimento celular, sendo talvez importante futuramente no tratamento de doenças cardíacas, câncer, doença renal e pré-eclampsia (Trask; Ferrario, 2007).

Outros estudos apontam que o papel da Ang 1-7 está relacionado com a regulação das principais ações relacionadas com a angiotensina II. (Fyhrquist $F$, Saijonma O. 2008). Dentre essas ações destaca-se a passagem em que o receptor Mas pode dimerizar com o receptor AT1, formando um heterodímero que antagoniza as ações da Angll e que nesse receptor promove uma interação da Ang1-7 com o Receptor Mas provocando numerosas estimulações protetoras como vasodilatação, geração de óxido nítrico (NO), além de possuir um efeito anti-trófico e ser capaz de amplificar a ação vasodilatadora da bradicinina (Ishikiriama, 2012).

\subsubsection{Angiotensina 1-9}

A angiotensina 1-9 (Asp $\left.{ }^{1}-\mathrm{Arg}^{2}-\mathrm{Val}^{3}-\mathrm{Tyr}^{4}-\mathrm{Il}^{5}-\mathrm{His}^{6}-\mathrm{Pro}^{7}-\mathrm{Phe}^{8}-\mathrm{His}^{9}\right)$ é conhecida como um peptídeo com pouca atividade biológica (Kramkowski; Mogielnicki; Buczko, 2006). Acredita-se que seja inativa até que a ECA a clive e libere Ang 1-7. Subsequentemente, Ang 1-7 é inativada pela liberação do dipeptídeo C-terminal para formar Ang 1-5 (Asp ${ }^{1}-\mathrm{Arg}^{2}-\mathrm{Val}^{3}-\mathrm{Tyr}^{4}-\mathrm{Il}^{5}$ ) (Chen et al., 2005). Por ser provavelmente o principal produto do metabolismo de Ang I em plaquetas, a Ang 1-9 pode estar envolvida na regulação da função plaquetária (Kramkowski, Mogielnicki, Buczko, 2006). Em concentrações micromolares, Ang 1-9 inibe a ECA (Snyder; Wintroub, 1986; Marcic et al., 1999) e potencializa a ação da bradicinina em seu receptor $B_{2}$ (Marcic et al., 1999). Em coração humano, a catepsina A (CATA) gera derivados Ang 1-9 e Ang 1-7 a partir de Ang I (Jackman et al., 2002). 


\subsubsection{Receptores de Angiotensinas}

A Ang II possui interações com diferentes tipos de receptores, conhecidos como $A T_{1}$ e $A T_{2}$. No músculo liso vascular, o receptor $A T_{1}$, membro da família de receptores ligados à proteína $\mathrm{G}$, possui 7 regiões transmembrânicas com 359 aminoácidos, é mediador da angiogênese e possui propriedades vasoconstritoras, enquanto que o receptor $\mathrm{AT}_{2}$ tem 363 aminoácidos, possuindo propriedades vasodilatadoras e inibindo a angiogênese. Os subtipos de receptores $A T_{1}$ e $A T_{2}$ apresentam estruturas genômicas e localizações diferentes, e também expressão e regulação específicas para cada tecido. Em quimiorreceptores do corpo da carótida, o receptor $\mathrm{AT}_{1}$ pode mediar a liberação de cálcio intracelular. As funções da Ang II, tais como constrição vascular, proliferação celular e liberação da aldosterona são conhecidas por serem mediadas via receptores $\mathrm{AT}_{1}$. Em ratos e camundongos, dois subtipos de receptores $A T_{1}$ foram clonados e caracterizados: $A T_{1 a}$ e $A T_{1 b}$ (Linderman; Greene, 2001; Paul; Mehr; Kreutz, 2006; Lam; Leung, 2002; Hirasawa et al., 2002; Inagami et al., 1994; de Gasparo; Siragy, 1999; de Gasparo et al., 2000; Speth; Thompson; Johns, 1995; Wright; Yamamoto; Harding, 2008) .

Há evidências de um receptor de angiotensina adicional denominado $\mathrm{AT}_{4}$, que interage com um peptídeo de Ang truncado, a Ang IV ou Ang 3-8 ( $\mathrm{Val}^{3}-\mathrm{Tyr}^{4}-\mathrm{Il}^{5}-\mathrm{His}^{6}$ $\left.\mathrm{Pro}^{7}-\mathrm{Phe}^{8}\right) . \quad \mathrm{AT}_{4}$ foi originalmente definido como específico com local de ligação de alta afinidade para Ang IV (Paul; Mehr; Kreutz, 2006) e parece estar relacionado à consolidação da memória, fluxo sanguíneo, reabsorção tubular renal e proliferação celular (Wright; Yamamoto; Harding, 2008).

O protooncogene Mas é sugerido como um receptor funcional de angiotensinas (Jackson, et al., 1988). O Mas é caracterizado como um receptor acoplado à proteína G, originalmente descrito como um fator envolvido na tumorogênese. Os efeitos do receptor Mas podem ser mediados por Ang 1-7 ou outros peptídeos de angiotensina, o que sugere alguma relevância funcional in vivo (Paul; Mehr; Kreutz, 2006). 


\subsection{VIAS ALTERNATIVAS DA GERAÇÃO DE ANGIOTENSINA II}

Por meio da via considerada alternativa, também pode ocorrer a produção da angiotensina II, gerada enzimaticamente pela ação da quimase humana e elastase-2 de rato (Santos et al., 2004; Becari et al., 2011 ) e de outros peptídeos ativos, também foram propostos. No entanto, acredita-se que novos componentes e funções do SRA ainda permanecem desconhecidos (Fyhrquist \& Saijonmaa, 2008).

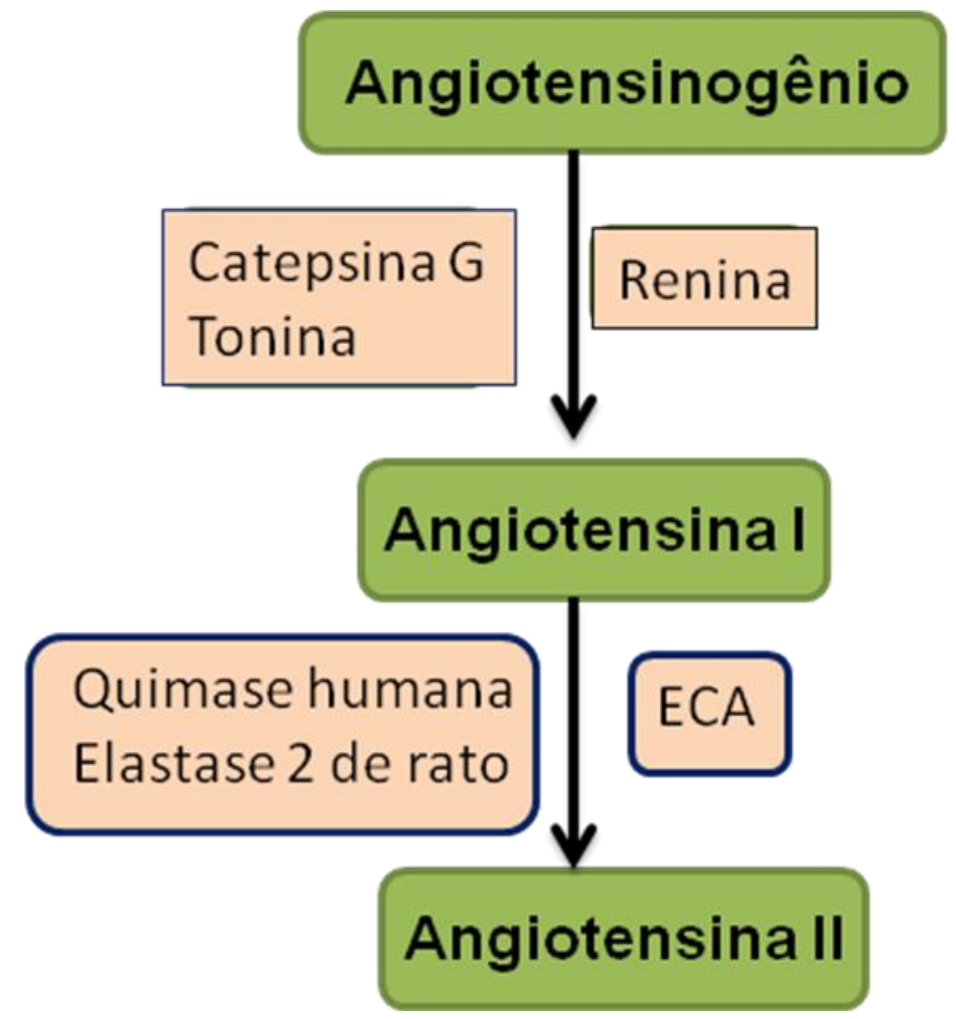

Figura 2: Esquema referente à via alternativa para a produção de angiotensina II,. (adaptado de Fyhrquist \& Saijonmaa; 2008).

Através do complexo macromolecular em que havendo a presença de heparina de proteoglicanos a quimase é armazenada nesse complexo e uma vez estimulada essa é secretada através dos grânulos das células presentes nos mastócitos (Takai S, Jin D, Muramatsu M, Miyazaki M. 2004). Esses grânulos são ativados através de estímulos que provêm de danos vasculares, porém torna se enzimaticamente inativa no tecido vascular normal e geralmente acarreta na produção de angiotensina II, que se torna presente somente em paredes dos vasos danificados ou com aterosclerose. (Fyhrquist.; Saijonmaa; 2008). Porém vale 
ressaltar que o inibidor de serina endógena de protease que está presente no fluido intersticial é considerado potente inibidor da enzima quimase (Kokkonen JO, Lindstedt KA, Kovanen PT.; 2003).

Já a Angiotensina 1-7 foi por muito tempo considerada desprovida de atividade biológica (Schiavone MT, Santos RA, Brosnihan KB et al 1988), mas a Ang 1-7 passou a ter uma maior importância devido a descoberta relativamente recente da ECA-2, devido a produção de Ang II a partir da enzima Ang 1-7 (Fyhrquist, F.; Saijonmaa, O. 2008). Além disso a Ang 1-7 provoca reações opostas em relação à Ang II em relação aos seus efeitos sistêmicos como vasodilatação (também provocada pela bradicinina) e antitróficos (Ferrario CM.2006; Watanabe T, Barker TA, Berk BC; 2005; Santos RA, Castro CH, Gava E et al.2006).

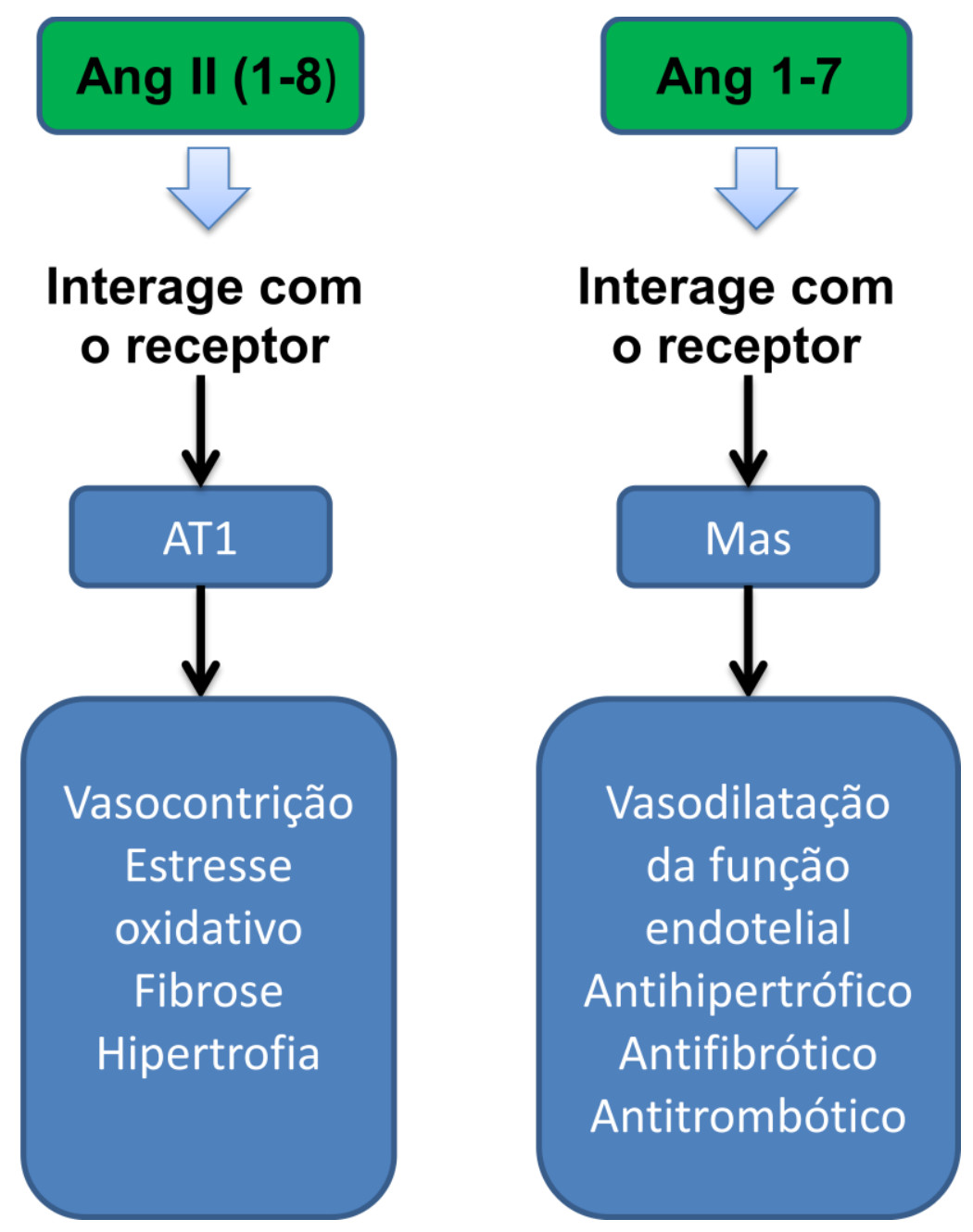

Figura 3: representação dos componentes presentes no SRA, seus respectivos receptores além de suas respostas sistêmicas e moleculares (adapatado de Fyhrquist, F.; Saijonmaa, O. 2008). 
Sendo assim muitos experimentos sugerem uma grande interação entre a Ang 1-7, prostaglandinas, bradicinina e NO (óxido nítrico), uma vez que estes apresentam ações sistêmicas que agem de uma maneira contrária àquelas provocadas pela Ang II, como por exemplo quando a Ang 1-7 ao se ligar no receptor Mas, que provoca ações vasodilatadora e antiproliferativa (Fyhrquist,F.; Saijonmaa,O. 2008).

Os inibidores da ECA provocam aumento dos níveis de bradicinina, que por sua vez está ligada à biossíntese de prostaglandinas, de maneira que ambas favorecem os efeitos provocados pelos inibidores da ECA. Sendo assim, devido a essa inibição, consequentemente estimula um aumento dos níveis de renina e a formação de Ang I. Sendo assim com um aumento da produção de Angl, ocorre o desvio para a produção por meio dessas vias metabólicas alternativas envolvidas nesse sistema provocando um aumento na produção de peptídeos como a Ang 1-7 (Goodman e Gilman, 2012).

\subsection{SISTEMA RENINA-ANGIOTENSINA LOCAL GENGIVAL}

Há muitas evidências acerca da existência de alguns componentes do SRA no tecido gengival e em fibroblastos gengivais de diferentes espécies (Ohuchi et al., 2002; Segawa et al., 2003; Berggreen e Heyeraas, 2003; Ohuchi et al., 2004; Santos et al., 2009). Ohuchi et al. (2002) sugeriram, por meio da utilização de drogas antagonistas de receptores de Ang II, que a proliferação de fibroblastos gengivais de cobaios estimulada pela fenitoína e nifedipina é mediada indiretamente por receptores AT1 presentes em fibroblastos gengivais em cultura. Os autores também sugeriram que Ang II é sintetizada localmente nestas células. Segawa et al. (2003) investigaram o efeito da Ang II sobre a produção de prostaglandina $E_{2}$ (PGE2) em fibroblastos gengivais humanos. Um antagonista de receptores AT1, mas não um antagonista de receptores AT2, foi capaz de inibir a produção de PGE2 estimulada pela Ang II administrada exogenamente. Berggreen e Heyeraas (2003) sugeriram, com a utilização de drogas antagonistas de receptores AT1, a existência destes receptores na polpa dentária e no tecido gengival de furão quando estudaram o efeito da Ang II sobre o fluxo sanguíneo em tecidos orais destes animais. Ohuchi et al. (2004) demonstraram que a Ang II induziu a proliferação de fibroblastos gengivais 
de coelhos de maneira concentração-dependente. Esta proliferação foi inibida por um antagonista de receptores AT1, porém não foi alterada por um antagonista de receptores AT2, sugerindo, portanto, que a proliferação de fibroblastos gengivais de coelho induzida pela Ang II nestas células em cultura ocorre via receptores AT1. Adicionalmente, em complemento aos achados farmacológicos, os autores demonstraram a presença dos receptores AT1 e AT2 nestas células com auxílio da técnica de Western blot.

Os receptores AT1 e AT2 foram encontrados na polpa dental por Souza et al. (2007), demonstrando a participação destes receptores de Ang II na pulpite pelo envolvimento tanto no estabelecimento como na modulação das alterações pulpares.

Estudos do nosso laboratório demonstraram a existência de um SRA local no tecido gengival de ratos. Experimentos mostraram que neste tecido existe a expressão de RNAm para todos os principais componentes do SRA (AGT, renina, ECA e receptores AT1a, AT1b e AT2) (Santos et al., 2009).

Além disso, ficou constatado recentemente que além da presença dos principais componentes SRA, ocorrem também indícios da presença de enzima elastase-2 no mesmo tecido, e que através de experimentos de imunoistoquimica confirmaram a presença de algumas dessas proteínas (AT1, AT2, Renina, ECA) no tecido gengival relacionado a cascata do SRA e quando administrado losartan ( antagonista de receptores AT1) ou alisquireno (inibidor da renina), ambos bloquearam a perda óssea no modelo de indução experimental da DP em ratos. O mesmo efeito não foi observado com o enalapril, administrado concomitantemente à indução da DP por um período de 14 dias) mas foi observado uma discreta diminuição na perda óssea alveolar deixando uma dúvida sobre o possível efeito tempo dependente sobre o método aplicado (Lima, 2011).

Outro trabalho do nosso grupo demonstrou que fibroblastos de gengiva e de ligamento periodontal, cultivados a partir de biópsias gengivais, expressaram alguns componentes do SRA como a AGT, renina, ECA e AT1. Foi detectada ainda expressão gênica diferenciada entre fibroblastos de gengiva e ligamento periodontal para a ECA, sendo significativamente maior nos fibroblastos da gengiva. Houve imunomarcação positiva tanto nos fibroblastos de gengiva quanto de ligamento periodontal compatível com a presença dos receptores AT1 e Mas em ambas as células. Pôde-se observar, por fim, que o contato com LPS de P. gingivalis e E. coli, 
na concentração de $10 \mu \mathrm{g} / \mathrm{mL} / 24 \mathrm{~h}$, não alterou a expressão dos componentes do SRA (Ishikiriama, 2012).

Em outro trabalho, nosso grupo demonstrou que houve expressão gênica de RNAm em tecido gengival sem diferenças estatisticamente significativas entre três condições de saúde periodontal (gengiva saudável, gengiva afetada por gengivite e gengiva afetada por periodontite) para os seguintes componentes do SRA: AGT, renina, ECA, ECA2, receptor de Ang I tipo 1(AT1) e receptor do tipo MAS. Houve imunomarcação para os receptores de angiotensina AT1 e AT2 sem diferenças estatísticas entre as três condições testadas. Os testes fluorimétricos mostraram maior atividade da ECA nas amostras afetadas por gengivite em comparação às amostras com saúde gengival $(p<0,05)$. Nos ensaios de HPLC, quando os homogenatos de tecido gengival foram incubados com Ang I, houve formação de Ang 1-7, Ang 1-9 e Ang II. Para as formações de Ang 1-7 e Ang II não houve diferenças estatísticas entre as três condições clínicas, enquanto que para Ang 1-9 houve maior formação nas amostras afetadas por periodontite em comparação às amostras com saúde gengival $(p<0,05)$. Pôde-se concluir que existe um SRA local no tecido gengival humano com diferenças entre saúde gengival, gengivite e periodontite, com maior atividade nos tecidos gengivais acometidos pela gengivite e periodontite. (Figueiredo, 2012).

Dados na literatura sugerem ainda a existência de um SRA intracelular que aparentemente pode ser funcional ou completo (De Mello, 2006; RE \& Cook,2006). Desta forma parece que esse SRA intracelular estaria relacionado ao controle de fluxo exercido pelo $\mathrm{Ca}^{+2}$, além de controles exercidos por genes nas células (Além et al.,1996).

\subsection{INTERAÇÃO ENTRE INFLAMAÇÃO E ANGIOTENSINA II}

$\mathrm{Na}$ doença periodontal, a inflamação e a destruição tecidual são eventos iniciais e constantes durante o processo mediado pelo hospedeiro em resposta à infecção bacteriana (Listgarten, 1987; Delima e Van Dyke, 2003; Van Dyke e Serhan, 2003).

A inflamação é um processo complexo que pode ocorrer nos tecidos em resposta a estímulos patológicos e usualmente leva à recuperação da integridade 
tecidual, mas se o reparo não é perfeitamente controlado o processo inflamatório pode resultar em dano tecidual permanente (Marchesi et al. 2008). Independente da etiologia do estímulo primário e do tecido envolvido, a inflamação classicamente segue três estágios: aumento na permeabilidade vascular (mudanças no calibre/fluxo vascular e incremento na permeabilidade vascular); recrutamento de leucócitos (rolamento/adesão/transmigração e quimiotaxia) e ativação dos processos para reparo tecidual. A Ang II está envolvida em todos estes três estágios da resposta inflamatória (Suzuki et al., 2003; Marchesi et al., 2008).

A Ang II, o principal peptídeo ativo do SRA, além de ser um mediador fisiológico do sistema circulatório, é reconhecida como um fator de crescimento que regula o crescimento celular e fibrose. Um grande número de estudos tem demonstrado que a Ang II está envolvida em eventos-chave da inflamação. Nesse processo, as células inflamatórias são equipadas com todos os componentes do sistema renina-angiotensina (SRA), podendo produzir angiotensina (Ang) II (Gomez et al., 1993; Owen e Campbell, 1998).

A Ang II é capaz de induzir dano vascular independente dos efeitos hemodinâmicos de indução da remodelação vascular e disfunção endotelial e aumento nos níveis de pressão arterial (Schiffrin, 2002) e isso pode ser explicado pelo menos parcialmente pelos efeitos pró-inflamatórios da Ang II.

A Ang II exerce seus efeitos pró-inflamatórios na vasculatura por meio da indução de integrinas, moléculas de adesão, citocinas e mediadores profibróticos e de crescimento pela ativação de fatores de transcrição e vias envolvendo espécies oxigênio reativas (Marchesi et al 2008). Também provoca suas respostas inflamatórias devido a suas ligações com os receptores AT1, desencadeando assim a cascata em que ocorrerá a sinalização intracelular que por consequência irá regular vários genes considerados pró-inflamatórios (Suzuki, 2003), Além disso ANG Il acaba que estimulando a inflamação através da mediação do NF-KB que por sua vez são induzidos por genes pro-inflamatórios (Phillips et al 2002 ; Tham et al 2002; Tham DM, Martin-McNulty B, Wang YX, et al. 2002).

Um estudo feito por de Cavanagh et al (2010), em ratos, concluiu que a inibição do SRA com bloqueadores dos receptores AT1 e com inibidores da ECA, além da diminuição da pressão arterial e proteção contra as ações profibróticas e proliferativas da Ang II, reduziram o estresse oxidativo principalmente pela prevenção da formação de espécies reativas de oxigênio derivadas da ativação da 
enzima nicotinamida adenina dinucleotídeo fosfato $(\mathrm{NAD}(\mathrm{P}) \mathrm{H})$ oxidase induzida pela Ang II.

Outro estudo feito por Borges Jr et al (2007) sobre marcadores próinflamatórios e estresse oxidativo na doença periodontal comprovou uma importante correlação entre marcadores de estresse oxidativo e a doença periodontal.

Somando-se as informações de que a Ang II está presente em todas as fases da inflamação (Marchesi et al 2008) (figura 4), que a inibição do SRA diminui o estresse oxidativo pela inibição da via Ang II de ativação da $\mathrm{NAD}(\mathrm{P}) \mathrm{H}$ oxidase (de Cavanagh et al 2010) e que a doença periodontal e o estresse oxidativo têm importante correlação (Borges Jr et al 2007) sugere-se que a inibição do SRA diminua os danos da doença periodontal durante sua progressão por meio da diminuição do estresse oxidativo pela inibição da via Ang Il-enzima $N A D(P) H$ oxidase.

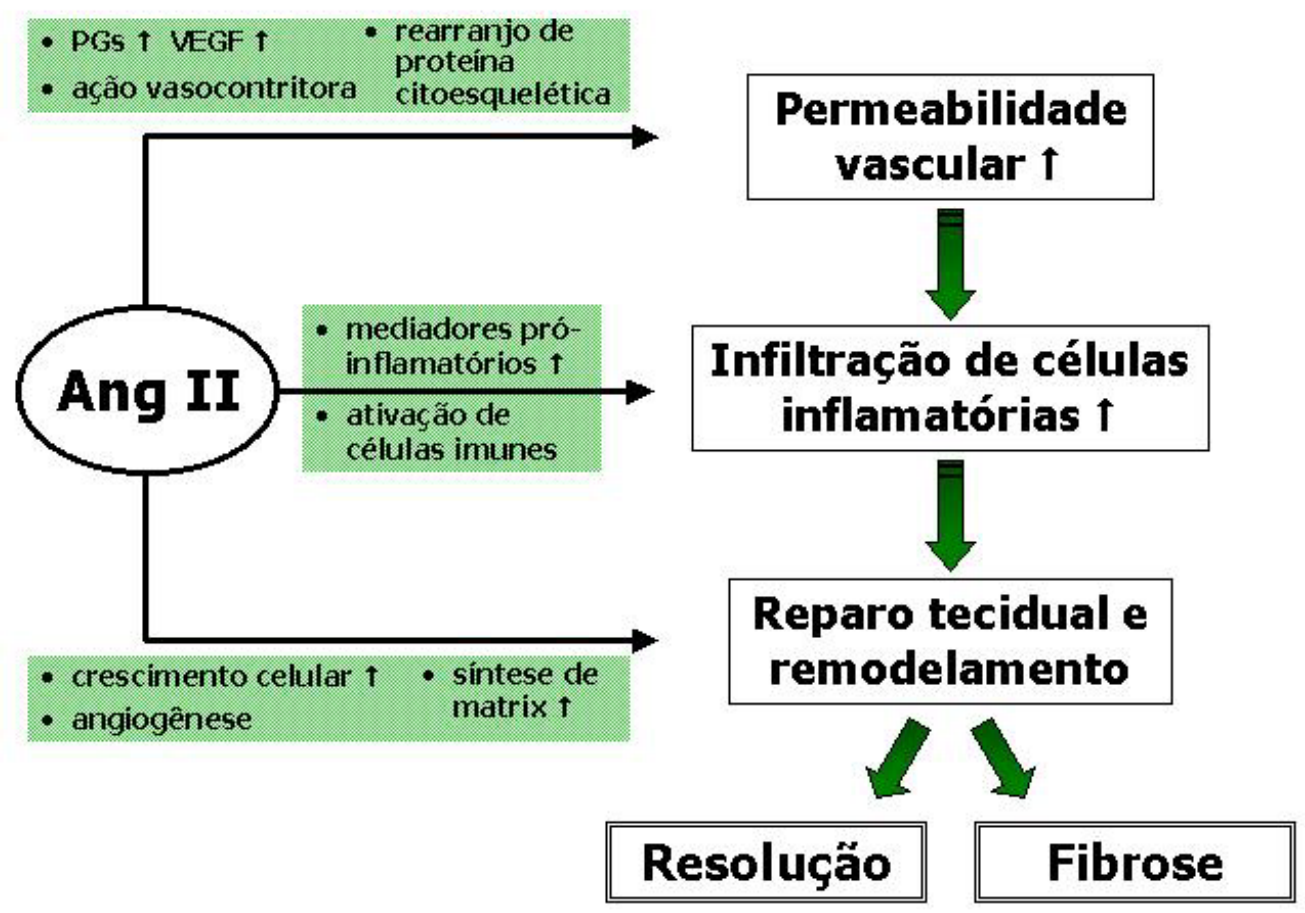

FIGURA 4: Ang II participa em importantes eventos da resposta inflamatória (modificado de Suzuki et al., 2003). PG - prostaglandinas; VEGF - fator de crescimento endotelial vascular. 


\subsection{DROGA QUE AFETA O SRA UTILIZADA NESTE ESTUDO}

O enalapril (maleato de enalapril) é uma pró-droga que é hidrolisada por esterases no fígado, produzindo sua forma ativa: o enalaprilato, que é um inibidor altamente potente da ECA. O pico de concentração plasmática da droga (forma ativa) acontece cerca de três a quatro horas após a ingestão. Em virtude de sua forte ligação à ECA tem meia-vida plasmática de cerca de 11 horas, sendo excretado na forma de enalapril inalterado ou enalaprilato pelos rins. O Enalapril sofre rápida absorção quando administrado por via oral e não sofre interferência devido à presença de alimento e este sofre biodisponibilidade de aproximadamente $60 \%$ após sua metabolização (Goodman e Gilman, 2012) (figura5).

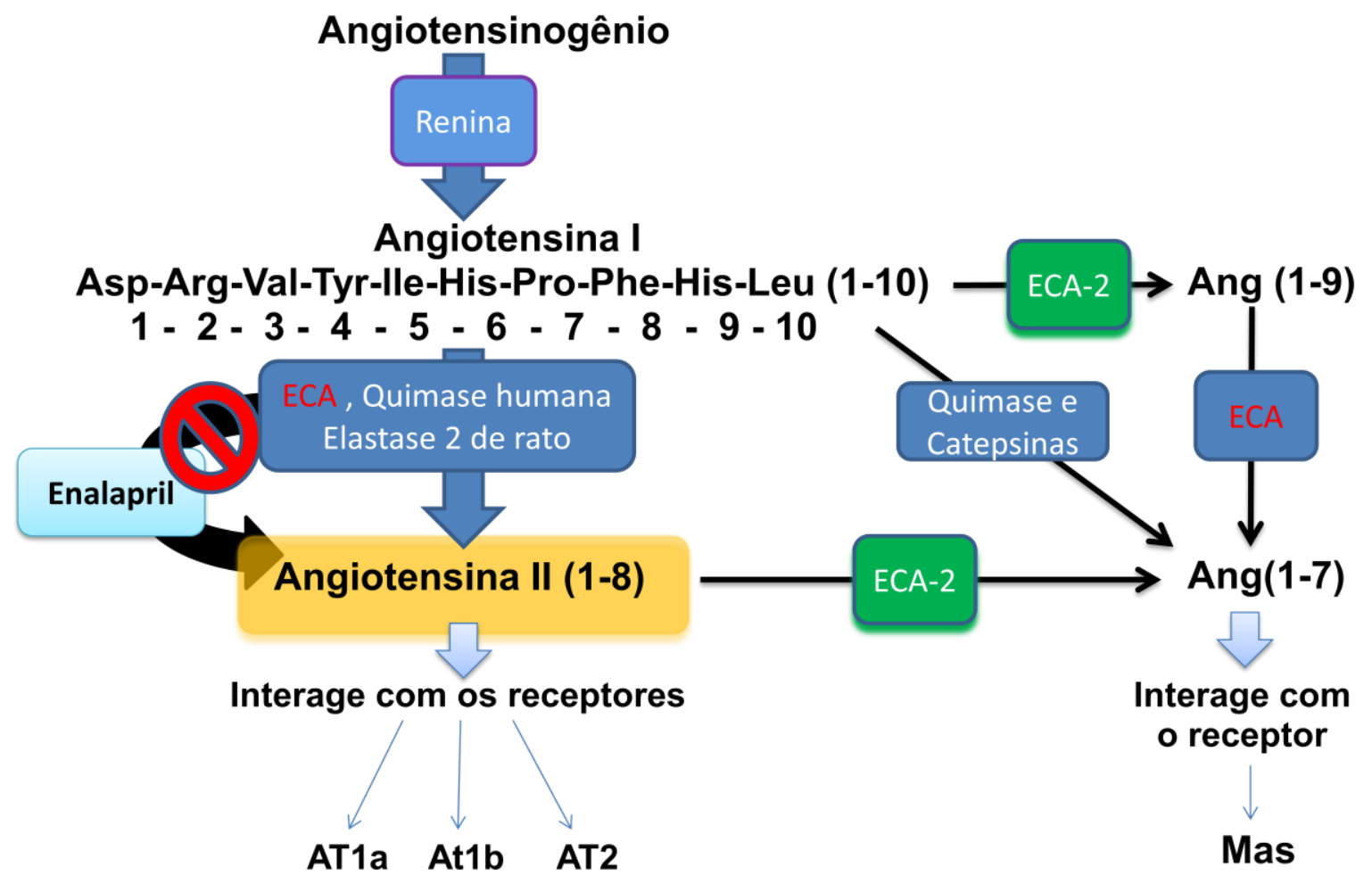

Figura 5: Ação do enalapril inibindo a ação da enzima conversora de angiotensina na cascata do sistema renina angiotensina. 


\subsection{MODELOS ANIMAIS PARA ESTUDO DA DOENÇA PERIODONTAL}

A pesquisa da doença periodontal requer o uso de animais de laboratório para o teste de agentes terapêuticos e para a avaliação da segurança e eficiência de técnicas, drogas e ferramentas para a melhora da cicatrização. Pelo fato da maior parte das doenças periodontais resultar em destruição irreversível do tecido conjuntivo e do osso alveolar, a indução da periodontite em humanos não representa um procedimento ético. Portanto, os modelos animais, nos quais a doença periodontal é induzida experimentalmente, continuarão indispensáveis para o estudo desta doença. A facilidade de manejo, o custo relativamente baixo e o curto período de tempo de estudo fazem do rato um instrumento versátil para estudo da doença periodontal (Madden e Caton, 1994). 
2 Proposição 



\section{PROPOSIÇÃO}

Conforme descrito anteriormente, a DP é uma afecção que envolve a participação de células residentes, células estruturais e mediadores inflamatórios. Experimentos recentes realizados em nosso laboratório mostraram que no tecido gengival de rato existe a expressão de RNAm para todos os componentes do SRA, presença da renina (experimentos de imunohistoquímica) e atividade da ECA (em homogenatos de tecido gengival). Desta forma, justifica-se a realização de investigações adicionais para que aspectos relativos à inibição da ECA e sua possível correlação com a progressão da doença periodontal induzida experimentalmente em ratos sejam esclarecidos. Isso poderá trazer contribuições importantes para um melhor entendimento dos mecanismos envolvidos na DP, os quais poderão ser úteis nas terapias preventivas e curativas dessa doença.

Portanto, o objetivo do presente projeto será:

1) investigar se o pré-tratamento e o pós tratamento com enalapril (inibidor da ECA) altera a progressão da DP induzida experimentalmente em ratos.

2) Investigar se ocorre alteração da perda óssea, em relação aos períodos tratados.

3) Observar por meio da técnica de reação de cadeia da polimerase quantitativa (qPCR) se a expressão dos respectivos alvos AGT, ECA, ECA-2 e dos receptores AT1a, AT1b, AT2 e Mas, serão afetadas pelo tratamento com enalapril em relação a indivíduos com ou sem a ação da DP. 

3 Materiais e MÉTOdos 



\section{MATERIAIS E MÉTODOS}

\subsection{ANIMAIS E CARACTERIZAÇÃO DOS GRUPOS EXPERIMENTAIS}

Foram utilizados ratos Wistar, machos, com peso entre 200 e $250 \mathrm{~g}$ (aproximadamente 60 dias), todos os grupos apresentaram peso padrão e tais animais foram provenientes do Biotério Central da Faculdade de Odontologia de Bauru/ Universidade de São Paulo (FOB/USP) e divididos em quatro grupos:

GRUPO 1: 20 animais foram pré tratados com água ou $20 \mathrm{mg} / \mathrm{Kg}$ de enalapril (inibidor da ECA) por gavagem durante 14 dias. Um dia após o último dia de tratamento, os animais foram submetidos à indução da doença periodontal por ligadura com fio de sutura 3.0 (Ethicon), permaneceram com a ligadura durante esse período e após 14 dias o grupo sofreu eutanásia

\begin{tabular}{|c|c|c|}
\hline 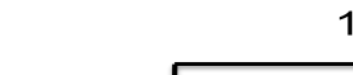 & 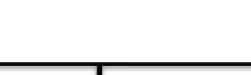 & 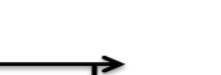 \\
\hline $\begin{array}{l}\text { pré tratamento } \\
20 \mathrm{mg} / \mathrm{kg} / \mathrm{dia} \text { de } \\
\text { Enalapril }\end{array}$ & $\begin{array}{l}\text { Indução da } \\
\text { Inoença } \\
\text { Periodontal }\end{array}$ & Eutanásia \\
\hline
\end{tabular}

GRUPO 2: 20 animais serão pré tratados com água ou $20 \mathrm{mg} / \mathrm{kg}$ de Enalapril (inibidor da ECA) por gavagem durante 14 dias. Um dia após o último dia de tratamento, os animais foram submetidos à indução da doença periodontal por ligadura com fio de sutura 3.0 (Ethicon), permaneceram com a ligadura durante esse período e após 7 dias o grupo sofreu eutanásia.

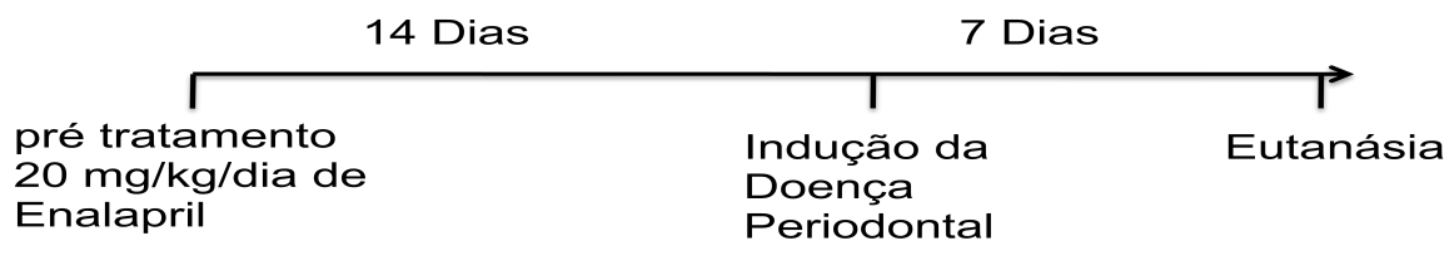


GRUPO 3: 20 animais foram pré tratados com água ou $20 \mathrm{mg} / \mathrm{kg}$ de Enalapril (inibidor da ECA) por gavagem durante 7 dias. Um dia após o último dia de tratamento, os animais foram submetidos à indução da doença periodontal por ligadura com fio de sutura 3.0 (Ethicon), permaneceram com a ligadura durante esse período e após 7 dias o grupo sofreu eutanásia.

\begin{tabular}{ll|l}
\multicolumn{1}{c}{7 Dias } & \multicolumn{1}{c}{7 Dias } \\
pré tratamento & & Indução da \\
$20 \mathrm{mg} / \mathrm{kg} /$ dia de & Doença \\
Enalapril & Periodontal &
\end{tabular}

GRUPO 4: 20 animais foram pré tratados com água ou $20 \mathrm{mg} / \mathrm{kg}$ de Enalapril (inibidor da ECA) por gavagem durante 7 dias. Um dia após o último dia de tratamento, os animais foram submetidos à indução da doença periodontal por ligadura com fio de sutura 3.0 (Ethicon), permaneceram com a ligadura durante esse período e após 14 dias o grupo sofreu eutanásia.

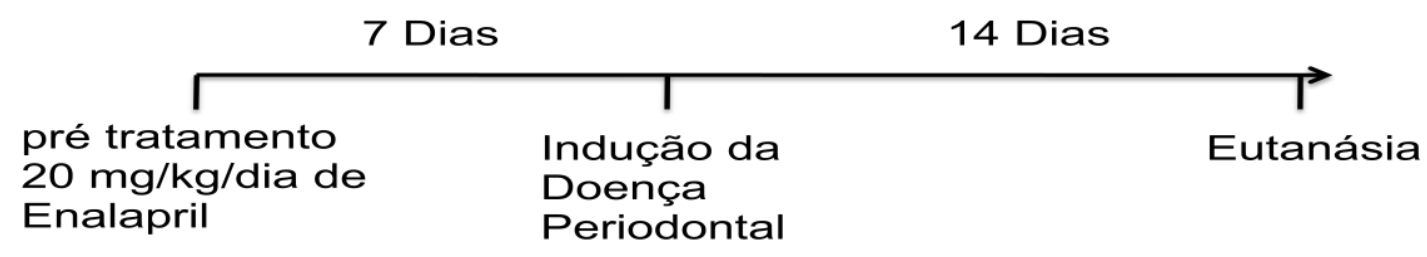

\subsection{DOENÇA PERIODONTAL INDUZIDA EXPERIMENTALMENTE EM RATOS}

A manipulação animal seguiu o protocolo aprovado pela Comissão de Ética no Ensino e Pesquisa em Animais da FOB/USP (Processo ㄲo 13-001/2012). Os animais foram anestesiados com Cloridrato de Ketamina e Cloridrato de xilazina (Dopalen ${ }^{\circledR}$ - 0,4 mL/kg e Anasedan ${ }^{\circledR}$ - 0,02 mL/kg, via intramuscular; de Almeida et al., 2007).

A ligadura constituiu-se de fio de seda preta 3-0 estéril e foi colocada na região cervical do primeiro molar inferior direito, tomando-se o cuidado de penetrar o fio no sulco gengival, portanto em íntima proximidade aos tecidos gengivais, ficando o nó na região mesial (Györfi et al., 1994; Lohinai et al.,1998). Os ratos de todos os 
grupos foram mantidos no biotério da Disciplina de Farmacologia da FOB/USP e alimentados com ração normal e água ad libitum.
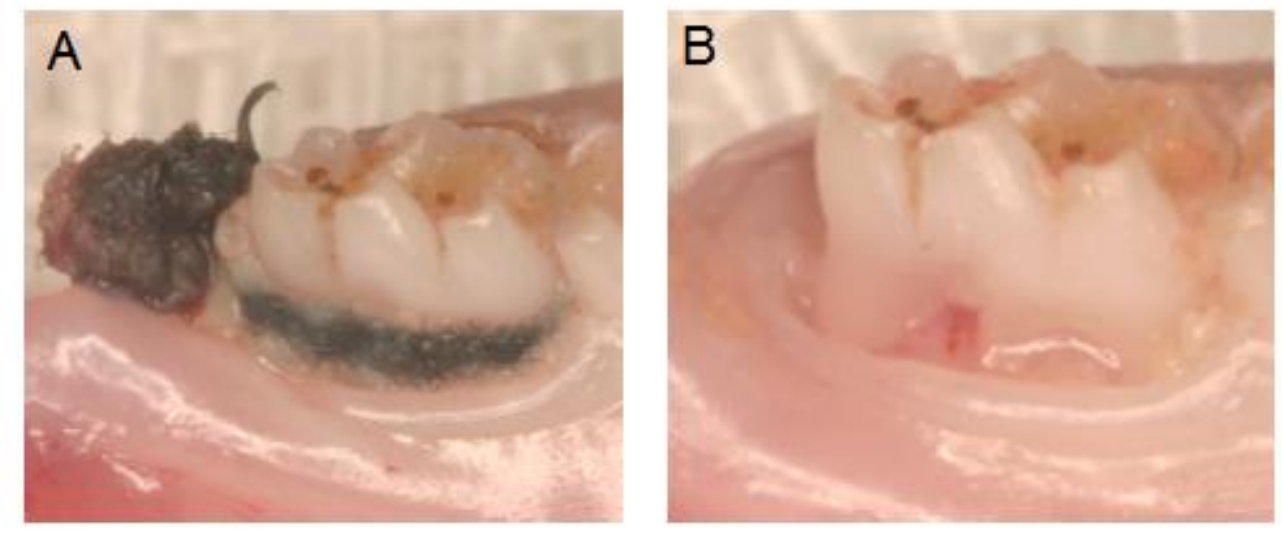

Figura 6: imagem representando a indução da doença periodontal no primeiro molar no rato. A: primeiro molar com o fio de sutura. B: primeiro molar após a retirada do fio de sutura.

O Inibidor da ECA utilizado foi o Enalapril, do qual foi Manipulado pela farmácia de manipulação Espefícia, em que tal inibidor foi manipulado e diluído em água na concentração de $10 \mathrm{mg} / 1 \mathrm{~mL}$, sendo que a cada administração do inibidor foram aplicados $2 \mathrm{~mL}$ por via oral (gavagem) durante todo o período de tratamento referente a cada grupo específico.

\subsection{OBTENÇÃO DE ESPÉCIMES PARA OS DIFERENTES EXPERIMENTOS}

Os animais foram eutanasiados com dose excessiva de anestésico nos tempos de 7 e 14 dias após a colocação da ligadura e tratamento com enalapril, durante os tempos citados, procedendo-se à obtenção de espécimes para os diferentes experimentos, que envolveram as seguintes análises durante a progressão da DP:

a) Volume ósseo alveolar;

b) Reação da cadeia da polimerase (qPCR) quantitativa; 
Imediatamente após a eutanásia dos animais a hemimandíbula com o fio de sutura foi removida. O material destinado à análise da perda óssea alveolar teve 0 tecido mole cuidadosamente descolado, armazenado em tudo de microcentrifuga contendo $500 \mu \mathrm{L}$ da solução conservadora RNAlater (Ambion, CA, Estados Unidos) e congelado a $-80^{\circ} \mathrm{C}$ para análises de expressão gênica por PCR. Já o tecido ósseo foi tratado com peróxido de hidrogênio 30 volumes $50 \%$, para análises tomográficas para avaliação da possível perda óssea alveolar provocada pela doença periodontal (SkyScan CT-Analyser).

\subsection{EXTRAÇÃO DO RNA}

No momento da extração do RNA das amostras, as mesmas foram descongeladas em gelo e em seguida transferidas para outro tudo de microcentrífuga contendo a solução de lise celular do RNeasy Mini Kit (Qiagen®, Germany). A etapa seguinte constituiu na homogeneização dos tecidos nesta solução seguida de uma centrifugação para separar os restos celulares do sobrenadante que consta o RNA. Este sobrenadante foi transferido para outro tubo contendo álcool absoluto, e esta mistura foi colocada numa coluna de sílica presente no kit, a qual reteu o RNA. Duas lavagens, com soluções específicas do kit, foram providas nestas colunas e a última etapa constituiu na eluição do RNA após a adição de água livre de RNAse nas colunas contendo o RNA.

\subsubsection{Quantificação e qualificação do RNA}

O aparelho utilizado foi o espectrofotômetro Nanodrop 1000 (Thermo Scientific $\AA$, Estados Unidos) o qual forneceu os dados de absorbância em 230, 260 e 280 nanômetros $(\mathrm{nm})$ após o carregamento de $2 \mu \mathrm{L}$ de amostra sem diluição. Este aparelho emite luz nos comprimentos de onda citados acima, e ao mesmo tempo detecta quanto dessa luz foi absorvida pela amostra. No caso do RNA, há a absorção da luz no comprimento de 260 nanômetros e o cálculo utilizado para a quantificação deste RNA é: [RNA] = Absorbância em 260 nanômetros $x$ fator de diluição $\times 50$ (constante para o RNA). 
A qualificação do RNA se dará pela razão estabelecida entre a absorbância em $260 \mathrm{~nm}$ e $280 \mathrm{~nm}$, assim como na razão entre $260 \mathrm{~nm}$ e $230 \mathrm{~nm}$. Os valores esperados para estas razões é entre 1,9 e 2,1, configurando em amostras puras.

\subsubsection{Transcrição Reversa}

Os RNAs que apresentaram pureza foram transcritos com a utilização do Quantitect Reverse Transcription Kit (Qiagen®), Germany). Este kit contém a enzima DNAse a qual será previamente utilizada para garantir a não contaminação com DNA genômico nas amostras de RNA. Após esta etapa, foram misturadas às amostras a enzima transcriptase reversa, os oligos DTs e randômicos e um tampão específico do kit. Toda esta mistura foi incubada a $37^{\circ} \mathrm{C}$ por 30 min no termociclador Verit (Applied Biosystems, USA).

\subsubsection{Reação em cadeia da polimerase quantitativa (qPCR)}

Após a transcrição reversa, os cDNAs foram misturados ao Taqman gene expression master mix (Applied Biosystems, USA) o qual contém a enzima taq polimerase, as base nitrogenadas A, T, C e G, o cloreto de magnésio e o tampão que confere à reação as condições ideais de amplificação. A esta mistura foram adicionados os primers e sondas marcadas com o fluoróforo FAM para a detecção quantificação dos componentes do sistema renina angiotensina. Os números de catálogo dos ensaios que contêm estes primers e sondas marcadas podem ser observados na Tabela 1.

\begin{tabular}{cc}
\hline Alvo & Número de catálogo (Applied Biosystems, USA) \\
\hline Angiotensinogênio & Rn00593114_m1 \\
Renina & Rn00561847_m1 \\
ECA & Rn00561096_m1 \\
ECA2 & Rn01416289_m1 \\
Receptor AT1a & Rn00578456_m1 \\
Receptor AT1b & Rn02132799_s1 \\
Receptor AT2 & Rn00560677_s1 \\
Receptor MAS & Rn00562673_s1 \\
GAPDH & Rn01775763_g1 \\
\hline
\end{tabular}

Tabela 1: Alvos da PCR quantitativa e códigos dos ensaios inventoriados (Applied Biosystems $\AA$ ) utilizados nos experimentos 
Após o preparo das reações em placas de 384 poços (Applied Biosystems, USA), esta foi alocada no aparelho de qPCR Viia 7 (Applied Biosystems, USA) e as seguintes condições de ciclagem foram utilizadas para a realização das amplificações: temperatura inicial de $95^{\circ} \mathrm{C}$ por 10 minutos para a ativação da taq polimerase seguido de 45 ciclos de $95^{\circ} \mathrm{C}$ por 15 segundo e $60^{\circ} \mathrm{C}$ por 1 minuto.

Para o estabelecimento das expressões relativas, de cada gene em estudo, à expressão do gene GAPDH (gene de referência), foi feita a subtração do Ct do alvo em estudo do $\mathrm{Ct}$ da beta actina $(\Delta \mathrm{Ct})$. Por conta de estes ensaios serem préfabricados e validados pela empresa Applied Biosystems, assumimos que a eficiência da reação será de $100 \%$, logo utilizaremos a fórmula 1+eficiência da reação $^{-\Delta \Delta C t}\left(2^{-\Delta \Delta C t}\right)$ para os cálculos de quantificação relativa.

\subsection{ANÁLISE DO VOLUME ÓSSEO POR MICROTOMOGRAFIA}

Após a eutanásia, as mandíbulas foram coletadas e armazenadas em tubo de microcentrífuga de $2 \mathrm{~mL}$ com $1,5 \mathrm{~mL}$ de álcool $70 \%$ e mantidos em $4^{0} \mathrm{C}$.

Para a análise microtomográfica foi utilizado o programa SkyScan CTAnalyser onde foram analisadas as mandíbulas. Para a avaliação do volume ósseo, foi selecionada uma área delimitada a partir da crista óssea alveolar até o ápice radicular do primeiro molar desde o extremo da face mesial até seu limite distal, conforme visualizado na figura 7 .

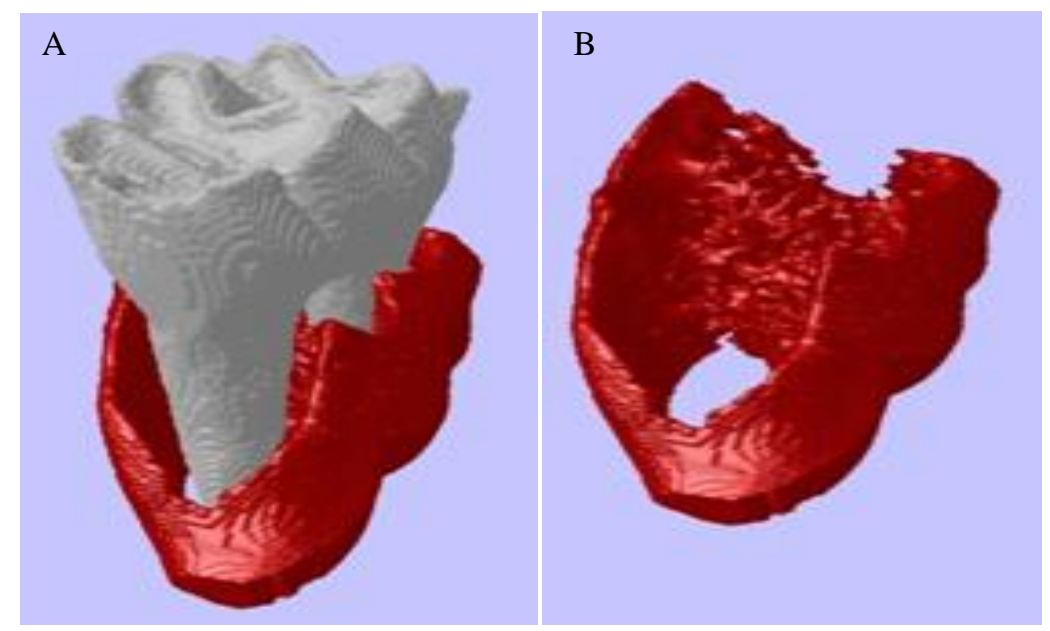

Figura 7: Representação do volume ósseo feita por análise através da técnica de microtomografia . A: primeiro molar analisado através da técnica de microtomografia, onde é representada a estrutura óssea e o dente. B: representa apenas a estrutura óssea analisada referente ao volume ósseo em $\mathrm{mm}^{3}$. 
Através desta técnica, pode se observar com uma maior riqueza de detalhes a perda óssea referente ao dente lesionado usado para a análise em questão.

\subsection{ANÁLISE ESTATÍSTICA}

Para a análise dos resultados tanto para a perda óssea alveolar, quanto para expressão gênica foi utilizado o teste $t$ de student. As comparações foram feitas entre os grupos de animais com doença periodontal versus aqueles com a doença periodontal fictícia (sham). O nível de significância adotado foi de $5 \%$. 

4 Resultados 



\section{RESULTADOS}

\subsection{ANÁLISE DO VOLUME ÓSSEO ALVEOLAR}

O volume ósseo alveolar nos animais com DP e tratados com água foi menor quando comparado aos animais submetidos à indução fictícia da DP (Sham) nos grupos 1 (9,86 $\pm 0,21$ vs $8,27 \pm 0,82 \mathrm{~mm}^{3}$ (média e desvio padrão) para Sham e DP respectivamente), $2\left(9,27 \pm 0,76\right.$ vs $8,38 \pm 0,35 \mathrm{~mm}^{3}$ para Sham e DP respectivamente) e $4\left(10,61 \pm 0,91\right.$ vs $9,14 \pm 0,52 \mathrm{~mm}^{3}$ para Sham e DP respectivamente) (Figura 8$)$.

Por outro lado, quando os animais foram tratados com enalapril não notou-se diferenças significativas entre os volumes ósseos dos animais com DP e animais Sham em todos os grupos analisados, sugerindo que o droga em questão foi capaz de diminuir a progressão da perda de volume ósseo alveolar nos animais com DP (Figura 8). No grupo 1 podemos notar ainda que os animais com DP tratados com enalapril possuem volume ósseo maior comparados aos animais com DP tratados com água, mostrando mais uma vez a ação protetora do enalapril na progressão da DP (Figura 8). 
4.2 ANÁLISE DO VOLUME ÓSSEO POR MICROTOMOGRAFIA COMPUTADORIZADA
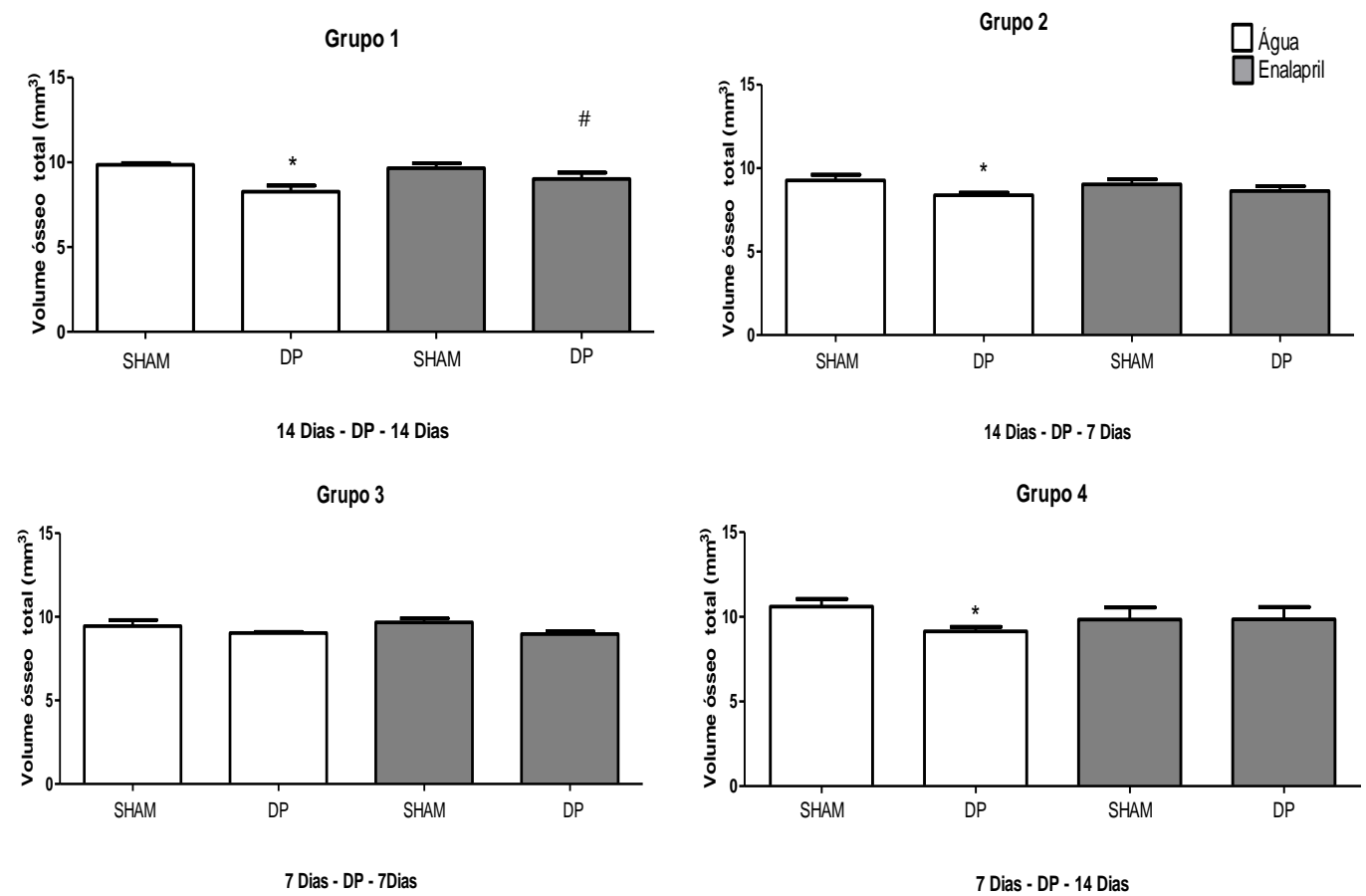

Figura 8: Volume ósseo alveolar ao redor do primeiro molar de todos os grupos estudados de acordo com o tempo de pré e pós-tratamento analisados por microtomografia computadorizada. Grupo 1 = ratos pré-tratados por 14 dias com água ou enalapril, indução da DP no $14^{\circ}$ dia e pós-tratamento por 14 dias com água ou enalapril; Grupo 2 = ratos prétratados por 14 dias com água ou enalapril, indução da DP no 14ํำ dia e pós-tratamento por 7 dias com água ou enalapril; Grupo 3 = ratos pré-tratados por 7 dias com água ou enalapril, indução da DP no $7^{\circ}$ dia e pós-tratamento por 7 dias com água ou enalapril e Grupo 4 = ratos pré-tratados por 7 dias com água ou enalapril, indução da DP no $7^{\circ}$ dia e pós-tratamento por 14 dias com água ou enalapril. * vs Sham tratado com água $\mathrm{e}^{\#}$ vs DP tratado com água. 
A figura 9 mostra quatro imagens advindas das análises tomográficas as quais ilustram a perda de volume ósseo alveolar. O grupo escolhido para esta representação foi o grupo 1, ou seja, aquele que houve pré e pós-tratamento com água ou enalapril por 14 dias.

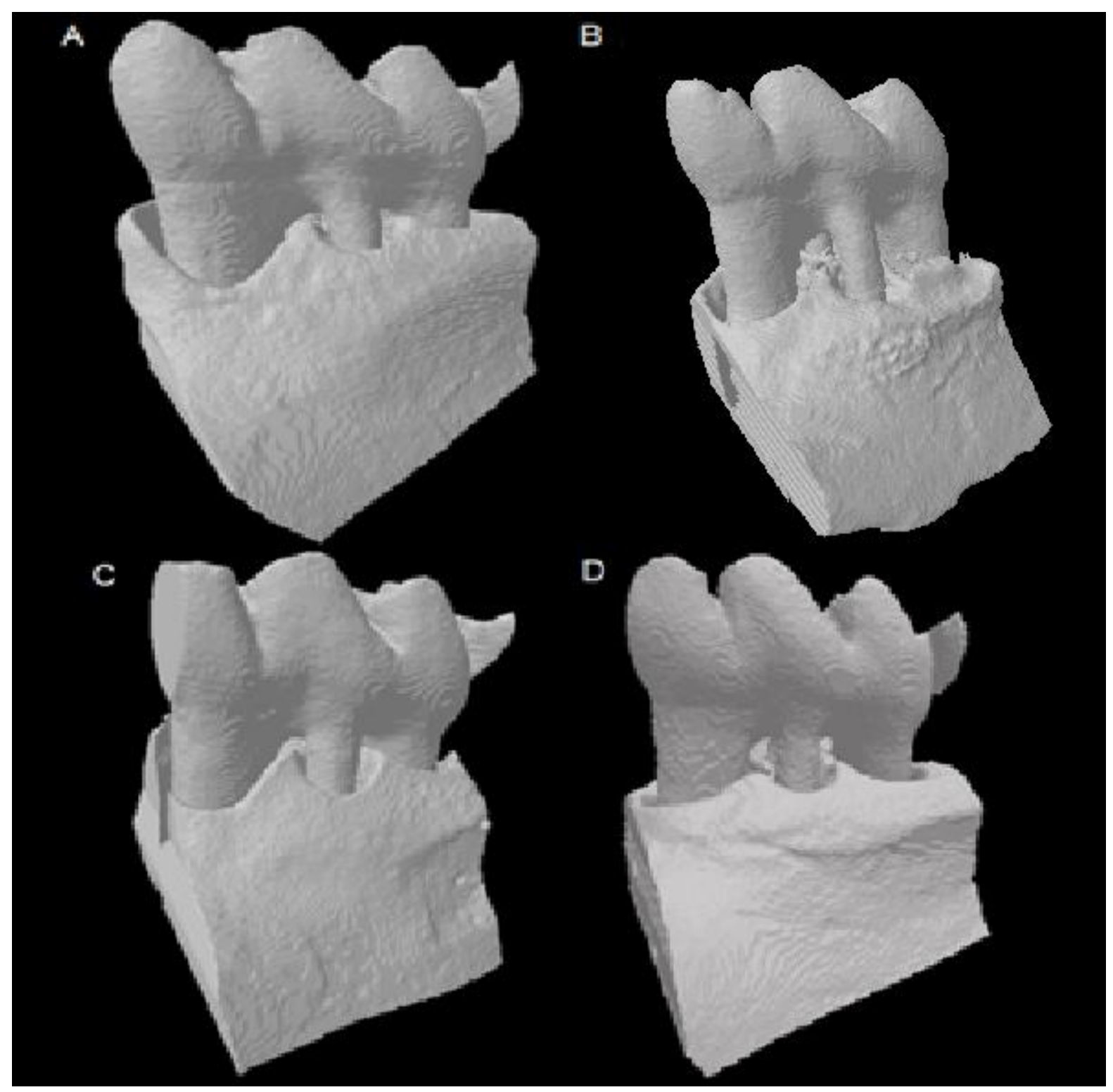

Figura 9 : Representação da perda óssea do grupo pré-tratado com água ou enalapril durante 14 dias e pós-tratado com água ou enalapril durante 14 dias. Através da técnica de microCT. A: Grupo tratado com água sem a indução da doença periodontal. B: grupo tratado com água com a indução da doença periodontal. C: grupo tratado com enalapril sem a indução da doença peridontal. D: grupo tratado com enalapril com a indução da doença periodontal. 


\subsection{ANÁLISE DA EXPRESSÃO GÊNICA NO TECIDO GENGIVAL DE TODOS OS COMPONENTES DO SISTEMA RENINA-ANGIOTENSINA}

Antes de relatar os resultados das expressões gênicas para os componentes do sistema renina-angiotensina, vale esclarecer que não foi possível detectar a expressão do RNAm para renina em qualquer amostra analisada.

Após as análises das expressões de RNAm observou-se que a DP induzida experimentalmente em ratos não causou modificações significativas na expressão do AGT (figura 10), ECA (figura 11), ECA-2 (figura 12), AT1a (figura 13), AT1b (figura 14), AT2 (figura 15) e receptor Mas (figura 16) nos animais tratados com água. Entretanto, nos animais com DP e tratados com enalapril detectou-se aumento de três vezes na expressão de AGT comparados aos animais Sham também tratados com enalapril (figura 10). O mesmo pôde ser visto na expressão do Receptor Mas que houve aumento de 1,7 vezes nos animais com DP em relação aos Sham induzidos (figura 16). Ambos os resultados supracitados foram encontrados nos ratos pertencentes ao grupo 4 (7-DP-14).

A expressão de RNAm para ECA encontrou-se aumentada de forma significativa nos animais do grupo 2 (14-DP-7) com DP e tratados com enalapril quando comparados àqueles também com DP tratados com água. Por outro lado a expressão de RNAm para os receptores AT1a está diminuída nos animais Sham do grupo 3 (7-DP-7) tratados com enalapril comparados aos animais Sham tratados com água. Ainda com relação ao receptor AT1a, os animais do grupo 2 (14-DP-7) com DP e tratados com enalapril tiveram queda significativa na expressão desse receptor comparados aos animais com DP tratados com água.

Os níveis de RNAm para ECA-2 encontra-se reduzido significativamente no grupo 1 (14-DP-14) nos animais com DP e tratados com enalapril comparados àqueles com DP tratados com água. O mesmo pode ser observado nos animais Sham tratados com enalapril comparados aos animais Sham tratados com água. No grupo 3 (7-DP-7) o tratamento com enalapril reduziu a expressão de ECA-2 nos animais com DP em relação aos animais Sham.

Para todos os outros alvos da cascata do SRA em todos os grupos analisados não foi possível detectar diferenças significativas. 


\subsubsection{Análise da expressão do RNAm para Angiotensinogênio}
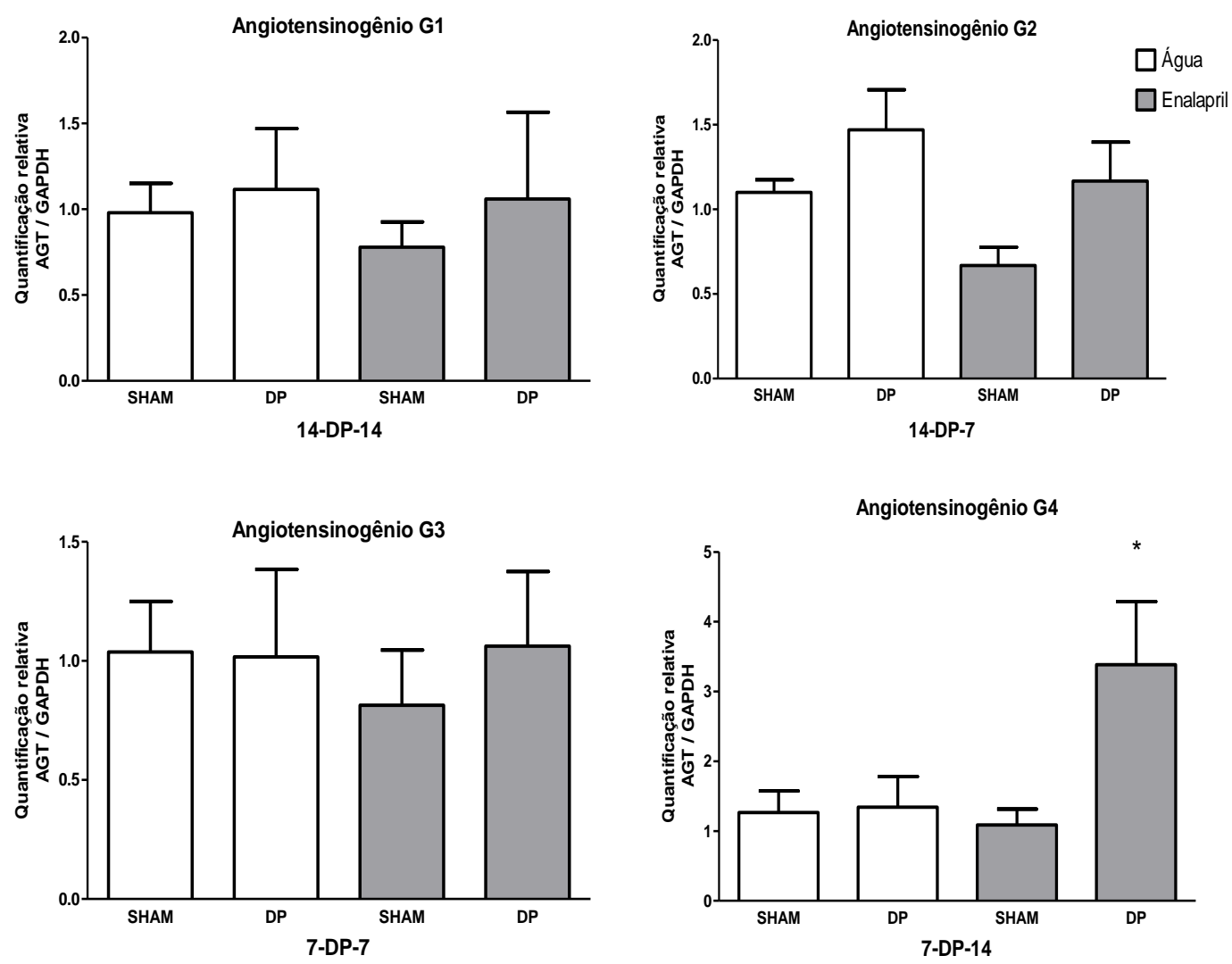

Figura 10: Representação gráfica da expressão do receptor de angiotensinogênio em relação ao GAPDH em amostras de animais sham e DP tratados com água ou enalapril, referente aos diferentes tempos de tratamento farmacológicos. SHAM: operação fictícia para a indução da doença periodontal . DP: doença periodontal induzida experimentalmente.

$\left(^{*}\right)$ diferença estatisticamente significativa $(p<0,05)$ em relação ao respectivo grupo sham. 


\subsubsection{Análise da expressão do RNAm para ECA}
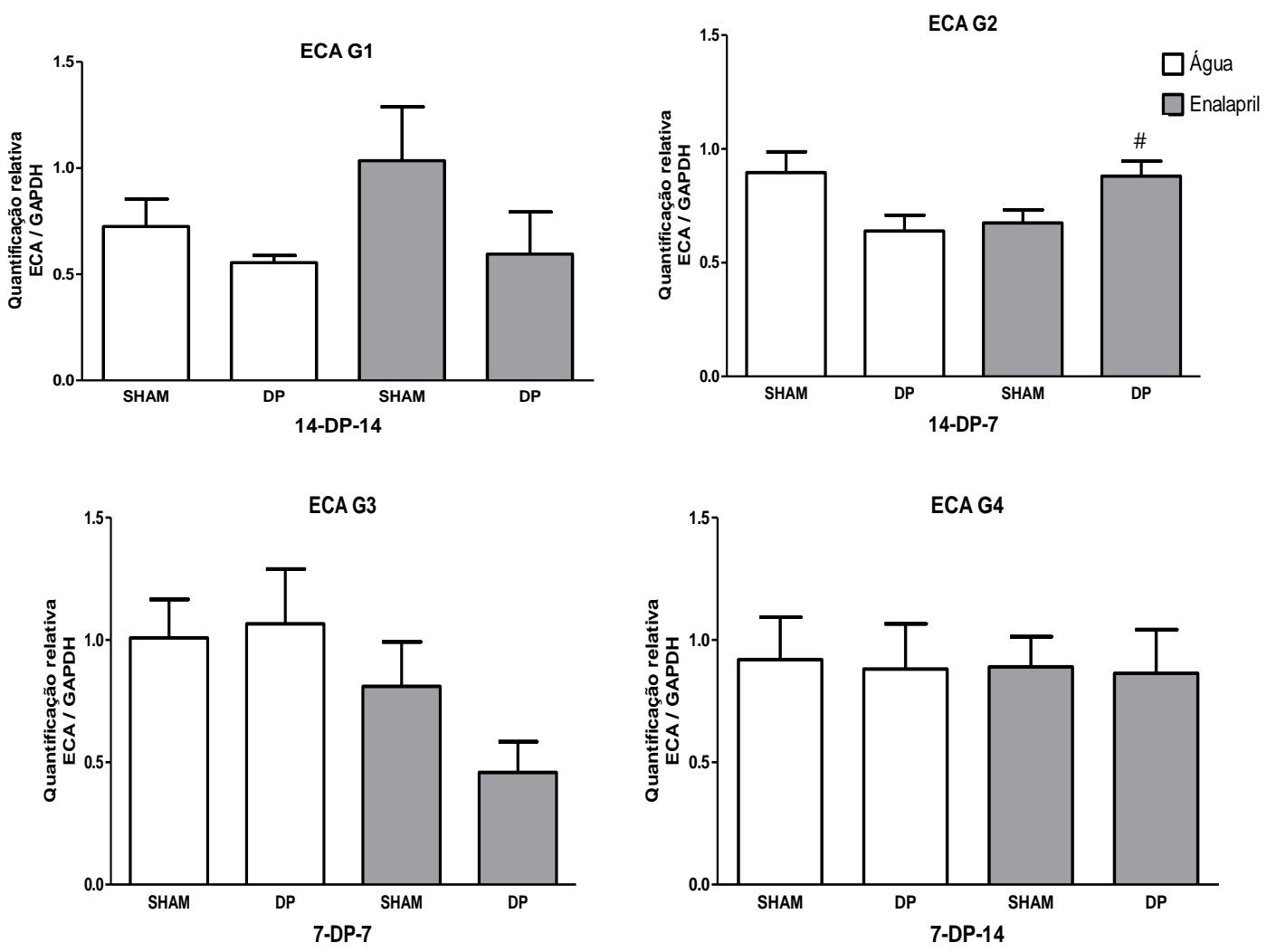

Figura 11: Representação gráfica da expressão do receptor da ECA em relação ao GAPDH em amostras de animais sham e DP tratados com água ou enalapril, referente aos diferentes tempos de tratamento farmacológicos. SHAM: operação fictícia para a indução da doença periodontal . DP: doença periodontal induzida experimentalmente. \# vs ratos com DP tratados com água. 


\subsubsection{Análise da expressão do RNAm para ECA-2}
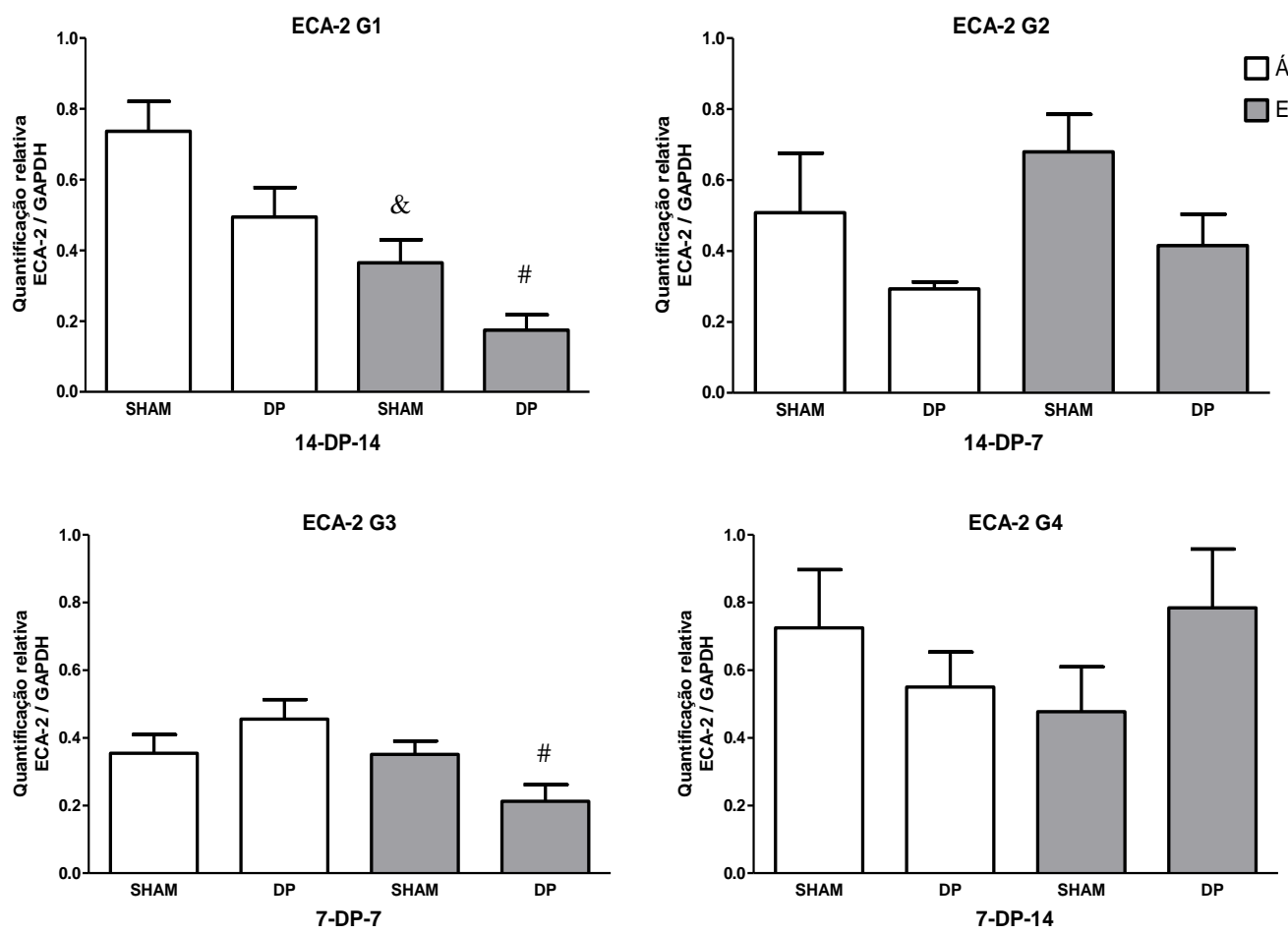

Figura 12: Representação gráfica da expressão do receptor da ECA-2 em relação ao GAPDH em amostras de animais sham e DP tratados com água ou enalapril, referente aos diferentes tempos de tratamento farmacológicos. SHAM: operação fictícia para a indução da doença periodontal . DP: doença periodontal induzida experimentalmente. \# vs ratos com DP tratados com água. \& vs ratos sham tratados com água. 


\subsubsection{Análise da expressão do RNAm para AT1a}
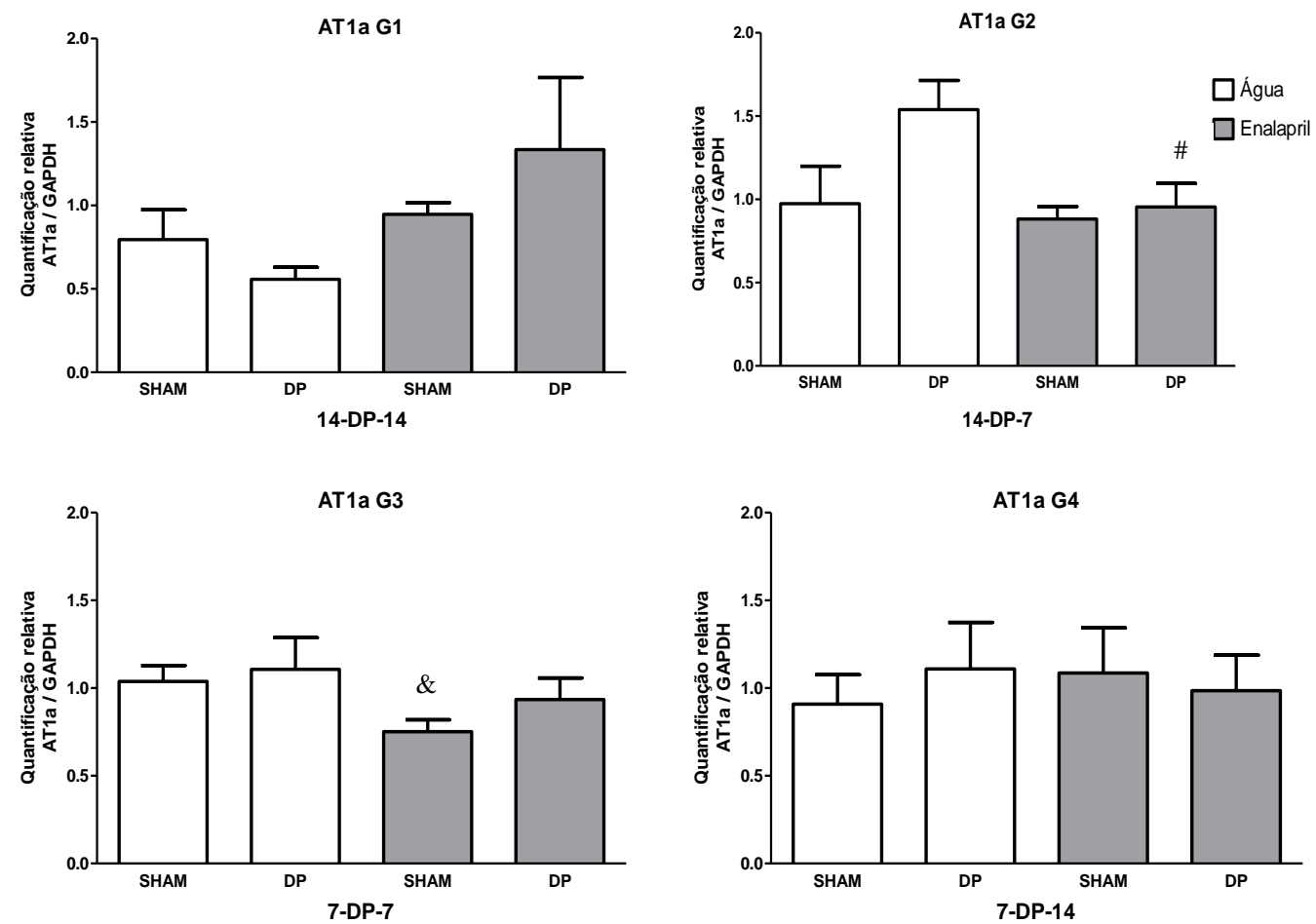

Figura 13: Representação gráfica da expressão do receptor da At1a em relação ao GAPDH em amostras de animais sham e DP tratados com água ou enalapril, referente aos diferentes tempos de tratamento farmacológicos. SHAM: operação fictícia para a indução da doença periodontal . DP: doença periodontal induzida experimentalmente. \# vs ratos com DP tratados com água. \& vs ratos sham tratados com água. 


\subsubsection{Análise da expressão do RNAm para AT1b}
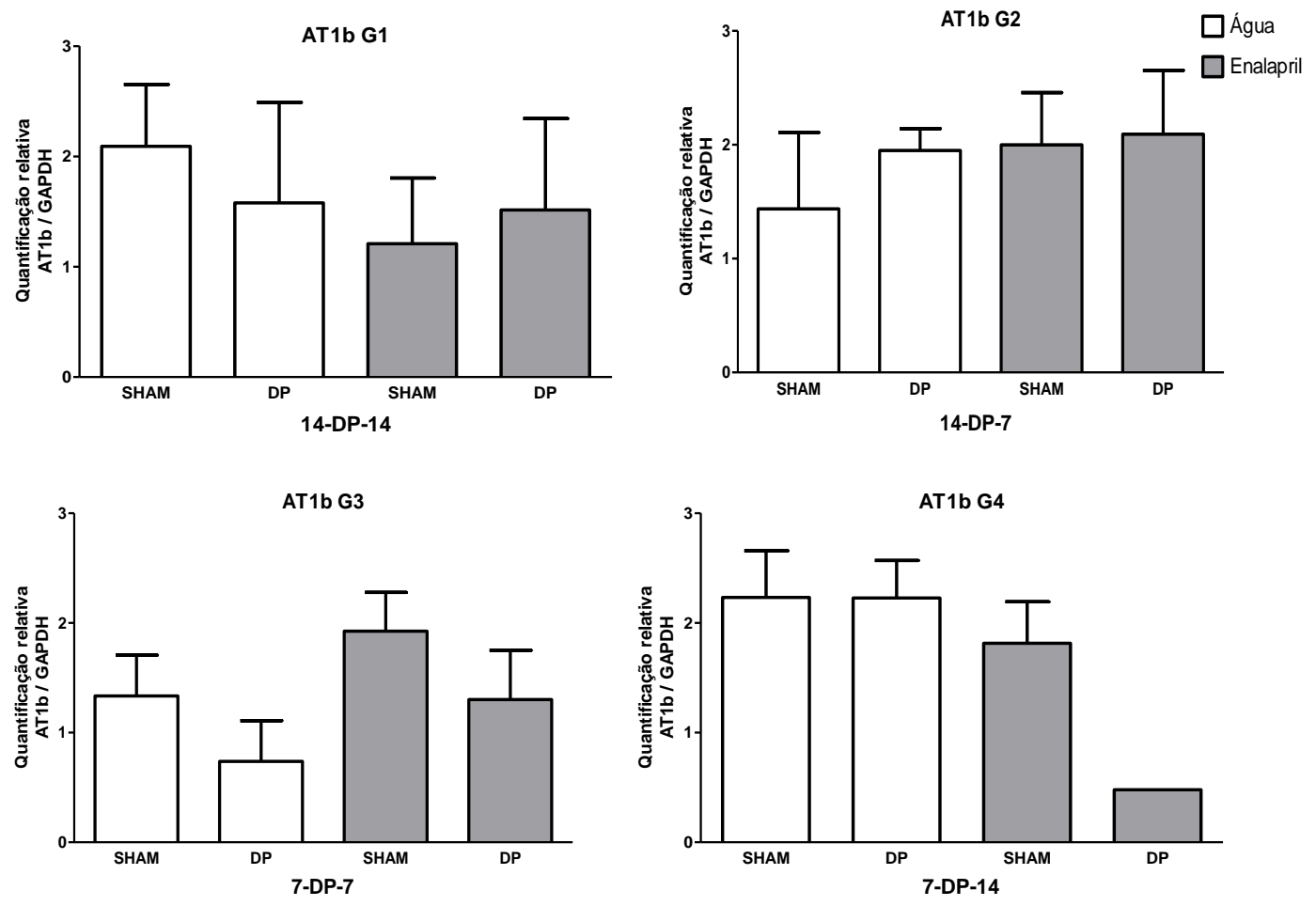

Figura 14: Representação gráfica da expressão do receptor da At1b em relação ao GAPDH em amostras de animais sham e DP tratados com água ou enalapril, referente aos diferentes tempos de tratamento farmacológicos. SHAM: operação fictícia para a indução da doença periodontal . DP: doença periodontal induzida experimentalmente.

$\left(^{*}\right)$ diferença estatisticamente significativa $(p<0,05)$ em relação ao respectivo grupo sham. 
4.3.6 Análise da expressão do RNAm para AT2
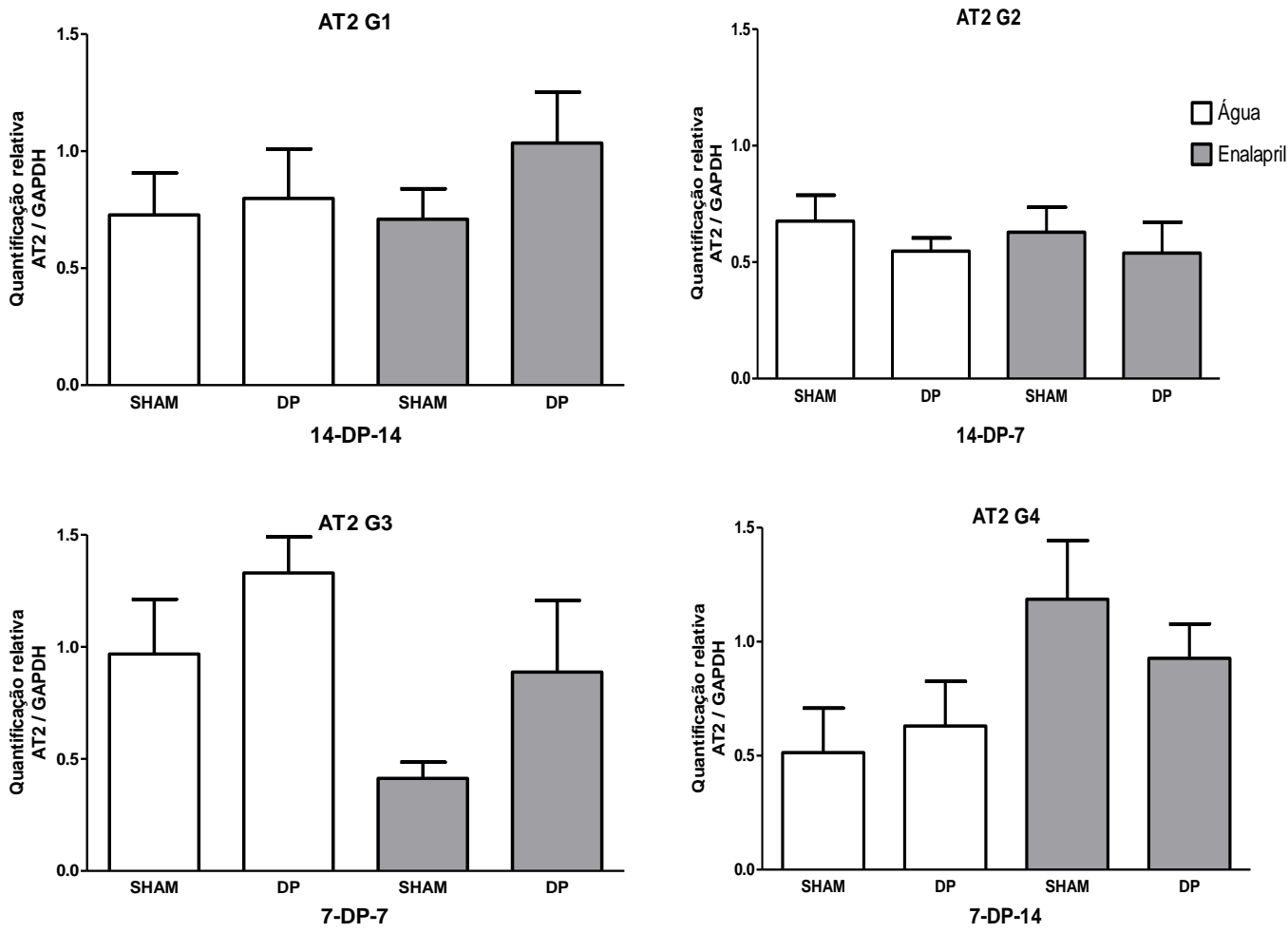

Figura 15: Representação gráfica da expressão do receptor da AT2 em relação ao GAPDH em amostras de animais sham e DP tratados com água ou enalapril, referente aos diferentes tempos de tratamento farmacológicos. SHAM: operação fictícia para a indução da doença periodontal . DP: doença periodontal induzida experimentalmente. 


\subsubsection{Análise da expressão do RNAm para Receptor Mas}
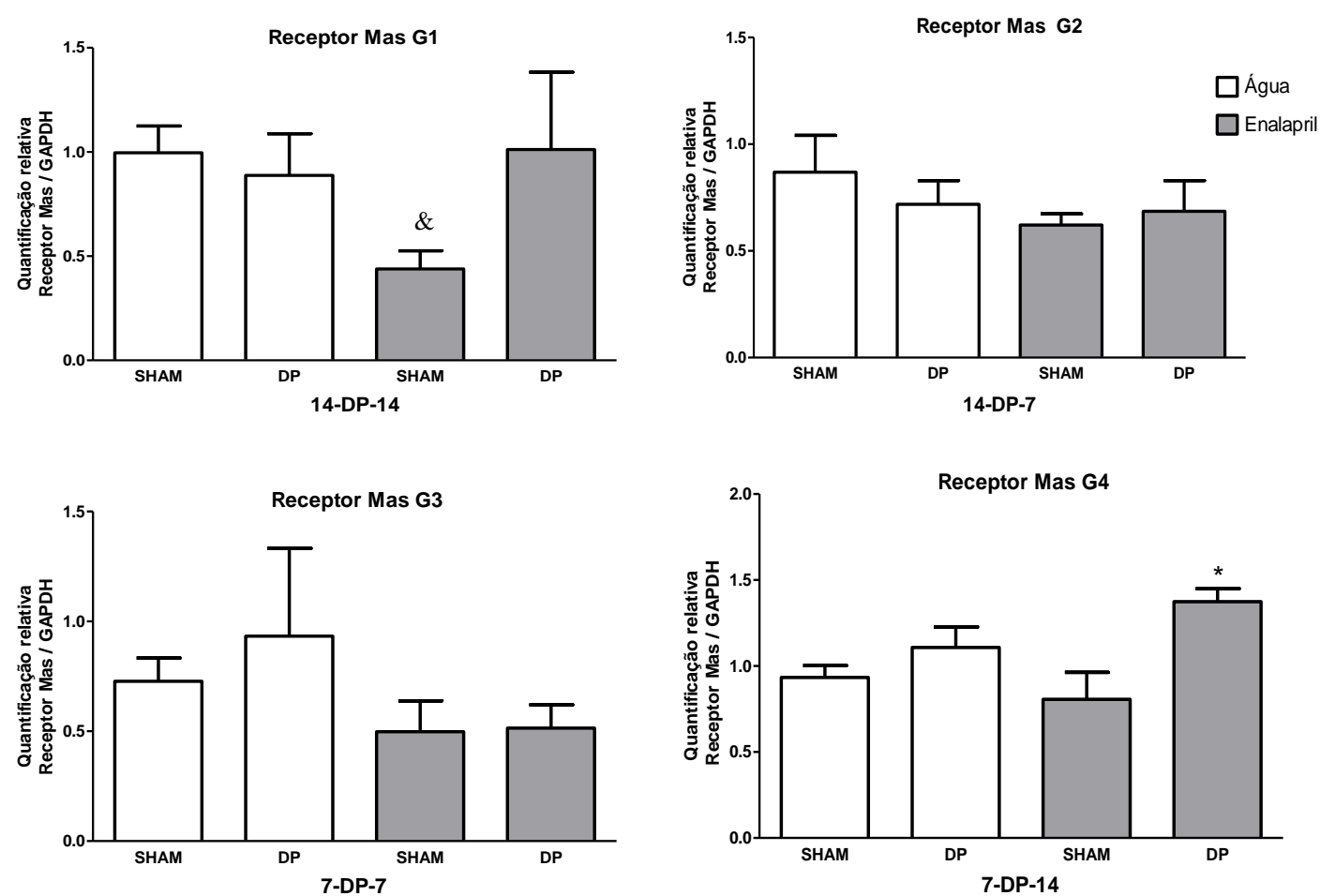

Figura 16: Representação gráfica da expressão do receptor Mas em relação ao GAPDH em amostras de animais sham e DP tratados com água ou enalapril, referente aos diferentes tempos de tratamento farmacológicos. SHAM: operação fictícia para a indução da doença periodontal . DP: doença periodontal induzida experimentalmente.

* diferença estatisticamente significativa $(p<0,05)$ em relação ao respectivo grupo sham. \& vs ratos sham tratados com água. 

5 Discussão 



\section{DISCUSSÃO}

Foram utilizados para a composição da amostra ratos Wistar, com idade de aproximadamente 60 dias, quando o ponto de contato dental já está bem estabelecido. O estabelecimento da função oclusal nesta espécie ocorre aos 25,28 e 40 dias para primeiro, segundo e terceiro molares, respectivamente, (após a irrupção dos molares aos 19, 22 e 35 dias de vida animal para primeiro, segundo e terceiro molares, respectivamente) (Madden, Caton 1994). No entanto, com a idade, ocorre uma perda óssea fisiológica resultante dos processos de remodelação óssea conforme a atrição interproximal dos molares (Weinberg, Bral 1999). Devido a esta reabsorção fisiológica, o presente estudo foi baseado na comparação com amostras de animais sham operados, ou seja, sem DP induzida experimentalmente.

Utilizou-se um modelo experimental bem estabelecido em ratos para indução da doença periodontal inflamatória , que envolve a colocação de ligadura ao redor da região cervical do primeiro molar inferior (Madden, Caton 1994). A inserção da ligadura e sua manutenção subgengival, porém sem destruir completamente a adesão propiciada pela junção dentogengival, possibilita o acúmulo progressivo e espontâneo de biofilme composto por bactérias presentes na própria microbiota do animal e na sua dieta, sem qualquer manipulação adicional. A ligadura age como um fator promotor da formação de biofilme na área dentogengival, provocando achatamento e deslocamento dos tecidos gengivais mesial e distal, bem como reduz a integridade tecidual pela ulceração ocasional do epitélio sulcular, o que permite interação entre hospedeiro e biofilme dentário.

Apesar de não ser uma doença espontânea, a manipulação do animal para sua indução é feita uma única vez e, a partir de então, a doença periodontal inflamatória progride naturalmente (Bezerra et al., 2000).

Modelos animais são largamente utilizados em benefício da compreensão da patogênese da doença periodontal inflamatória e na avaliação de suas variadas modalidades terapêuticas (Madden, Caton 1994; Bezerra et al., 2000; Rodini et al., 2008; Oliveira et al., 2008). Embora não se possam esperar respostas idênticas e agressões semelhantes entre as diferentes espécies, modelos animais podem funcionar como modelos de tendências biológicas e fornecer informações 
impossíveis de se obter em humanos. Neste sentido, rato geralmente é alvo de estudos experimentais da doença periodontal inflamatória, devido às grandes semelhanças com os humanos em relação à anatomia da região de molares, inclusive da junção dentogengival, baixo custo de pesquisa, fácil manuseio e disponibilidade de utilização de várias raças com diferentes estados microbiológicos e imunológicos (Madden, Caton 1994; Weinberg, Bral 1999). Além disso, estudos longitudinais da doença periodontal inflamatória em humanos levantam vários problemas como a determinação do nível de atividade da doença, riscos individuais e suscetibilidade à progressão da doença. Então, é importante escolher um modelo animal experimental que possua características semelhantes com relação à anatomia e à doença periodontal inflamatória humana (Weinberg, Bral 1999). Uma das vantagens de se estudar uma doença experimentalmente induzida é poder observar seu curso ao longo do tempo, a fim de se compreender sua patogênese e definir a melhor forma de tratá-la (Madden, Caton 1994).

A doença experimentalmente induzida em ratos mostrou-se capaz de promover a diminuição do volume ósseo alveolar no presente estudo, assim como em outros trabalhos (Lima 2011 ; Oliveira 2007). Na figura 8 podemos notar que, tanto 7 quanto 14 dias após a indução da DP, houve diminuição do volume ósseo alveolar nos ratos que receberam água durante o período. Por outro lado, no tratamento com enalapril nos grupos 1, 2 e 4 observou-se que a droga em questão foi capaz de conter a perda do volume ósseo alveolar nos animais com DP comparados aos animais Sham também tratados com enalapril. Vale destacar, que nestes grupos o período mínimo de tratamento com enalapril foi de 21 dias, ou seja, houve tratamento antes e após a indução da DP.

Os resultados acima sugerem que esta droga precisa de um período superior a 14 dias para promover a proteção contra a perda óssea em ratos com DP, uma vez que notamos no trabalho de Lima 2011, o qual também testou a eficácia do enalapril na progressão da DP sem o pré-tratamento, que após 14 dias de tratamento com enalapril os animais com DP apresentaram perda óssea alveolar.

Assim como esperado e demonstrado no trabalho de Lima 2011, o presente estudo mostrou que o tratamento com enalapril nos animais Sham operados não provoca modificação no volume ósseo alveolar. Porém, os animais com DP que receberam pré e pós-tratamento com enalapril durante 14 dias (28 dias no total) apresentaram um volume ósseo maior quando comparados aos animais com DP 
tratados com água pelo mesmo período (Figura 8). Este resultado não foi observado nos demais grupos com períodos de tratamento inferiores, sugerindo mais uma vez a necessidade de maiores períodos de tratamento com enalapril para o alcance de resultados preventivos da perda de volume ósseo alveolar em ratos com DP.

Uma possível explicação para este efeito protetor conferido pelo enalapril é a ação de diminuir a disponibilidade de Ang II para interagir com os receptores AT1, o que tem sido demonstrado como um dos fatores na promoção da reabsorção óssea (Kaneko et al. 2011). Tem sido demonstrado ainda que o sistema reninaangiotensina está presente e ativo em microambientes ósseos (Lavoie e Sigmund, 2003).

Pérez-Castrillón et al (2003) mostraram que mulheres hipertensas com maiores níveis de Ang II circulante responderam ao tratamento de 1 ano com enalapril, uma vez que foi detectado aumento significativo da densidade mineral óssea em comparação às mulheres que não tomaram a droga.

Camundongos nocautes para os receptores AT1a apresentam maior massa óssea (tíbia) comparados aos camundongos selvagens (Kaneko et al. 2011). Neste mesmo trabalho foi demonstrado ainda que tanto número de trabéculas ósseas quanto a densidade conectiva da tíbia estão aumentadas nos animais nocautes para AT1a, sugerindo que a Ang II pode promover reabsorção óssea.

No presente estudo os níveis de Ang II local e circulante não foram avaliados, porém a expressão de RNAm para o AGT (grupo 4) no tecido gengival, adjacente à área da perda de volume ósseo, encontrou-se aumentada de forma significativa nos animais tratados com enalapril e com DP. Este aumento provavelmente foi por conta da própria DP que tende a aumentar os níveis de Ang II após o aumento de AGT, renina e ECA, e também pelo feedback negativo causado pela inibição da ECA pelo enalapril. Entretanto, acredita-se que a droga foi eficaz na inibição da ECA diminuindo os níveis de Ang II neste caso, pois não foi observada perda de volume ósseo alveolar nos animais com DP.

Os mecanismos envolvidos na perda de volume ósseo causada pela DP podem ser explicados pelo aumento de Ang II por conta da inflamação instalada durante a progressão da DP (Suzuki et al. 2003). Hatton et al. (1997) demonstraram que na presença de Ang II os osteoclastos em co-culturas com osteoblastos promovem mais reabsorção óssea em calvária de ratos. Tem sido relatado ainda que a Ang II acelera o processo de osteoporose pela maior atividade dos 
osteoclastos (Shimizu et al. 2008). Esta atividade aumentada dos osteoclastos está associada ao aumento da expressão de RANKL pelos osteoblastos, ligante este que uma vez acoplado ao receptor RANK na superfície dos osteoclastos promove o aumento da reabsorção óssea. Vale destacar que o tratamento com a droga losartan, antagonista dos receptores AT1, desacelera este processo (Shimizu et al. 2008 e Rajkumar et al. 2013), assim como a droga enalapril (Rajkumar et al. 2013). Neste mesmo trabalho também se bloqueou os receptores AT2 com a droga antagonista PD123329, entretanto os níveis de RANKL e a atividade dos osteoclastos continuaram aumentados, sugerindo mais uma vez que é a interação da Ang II com os receptores AT1 que promove a perda de volume ósseo durante o processo inflamatório. Por outro lado, Izu et al. (2009) demonstraram que os receptores AT2 quando bloqueados, ou nocautes em camundongos, favorecem ao aumento da massa óssea em fêmur de camundongos adultos. Neste estudo os autores notaram que o antagonismo aos receptores AT2 promove diminuição do número de osteoclastos na superfície óssea após estímulo com Ang II.

Até aqui foram discutidos os mecanismos envolvendo os osteoclastos no metabolismo ósseo, porém sabe-se que os osteoblastos conferem papel fundamental no processo de formação óssea. No trabalho de Hagiwara et al. (1998) foi relatado que a Ang II ligada aos receptores AT1 nos osteoblastos causou inibição na expressão de RNAm para osteocalcina, uma importante proteína para a maturação dos osteoblastos. Além disso, a atividade da fosfatase alcalina, importante proteína da diferenciação dos osteoblastos, também diminuiu indicando que a Ang II além de favorecer a atividade dos osteoclastos, desfavorece a ação dos osteoblastos.

O processo de envelhecimento também é conhecido pela diminuição da deposição de tecido ósseo. Gu et al. 2012 demonstraram que a tíbia e o fêmur de ratos idosos possuem menos densidade mineral óssea comparados aos animais jovens. Estes autores associaram este evento ao aumento significativo da expressão de RNAm do AGT e renina nos ratos idosos, com consequente aumento da Ang II nos ossos avaliados.

A Ang 1-7 quando ligada ao receptor do tipo Mas parece mediar positivamente 0 processo anti-inflamatório, pois tem sido relatado que este heptapeptídeo reduz a migração de leucócitos e a expressão de citocinas inflamatórias tais como TNF- $\alpha$, IFN- $\gamma$, IL-1 $\beta$ e IL-6 (Sukumaran et al. 2011). Estas 
ações parecem estar associadas a diminuição da LOX-1 (receptor 1 tipo lectina de lipoproteína de baixa densidade) causada pela Ang 1-7 (Wang et al. 2013). Entretanto, não há dados na literatura mostrando a possível ação da Ang 1-7 no metabolismo ósseo.

No presente estudo foi avaliada a expressão de RNAm para o receptor do tipo Mas a qual encontra-se aumentada nos animais do grupo 4 (7-DP-14) com DP e tratados com enalapril. Tanto a DP quanto o tratamento com o inibidor da ECA pode favorecer o aumento da expressão de Ang 1-7, pois durante o processo inflamatório instalado o organismo, como ação protetora, pode passar a produzir agentes antiinflamatórios como a Ang 1-7. Além disso, o bloqueio da ECA causará um acúmulo de Ang I o qual é substrato para as endopeptidases na formação de Ang 1-7 (Ferreira e Santos 2005).

A expressão de RNAm para a ECA no presente estudo mostrou-se aumentada nos animais tratados com enalapril e com DP no grupo 2 (14-DP-7). Sabe-se que a inflamação pode aumentar os níveis de RNAm (Miguel-Carrasco et al. 2010) e a atividade da ECA (Figueiredo 2011), assim como a inibição da ECA pela ação do enalapril pode, por feedback negativo, levar a uma produção de mais RNAm para a ECA. No trabalho de Ishikiriama (2012) os níveis de RNAm para ECA encontrou-se aumentados em fibroblastos humanos em cultura estimulados com LPS. Estes dados sugerem novamente que a condição inflamatória tende a aumentar a expressão de Ang II por aumentar os componentes da cascata do SRA.

Os níveis de RNAm dos receptores AT1a no grupo 3 (7-DP-7) encontram-se diminuídos nos animais Sham tratados com enalapril. A diminuição dos níveis de Ang II pode ter sido a causa desta queda. O mesmo pôde ser visto no grupo 2 (14DP-7) nos animais com DP tratados com enalapril, e este fato pode ter conferido proteção na progressão da DP já que estes animais tratados com enalapril não apresentaram perda de volume ósseo alveolar muito provavelmente pela menor interação da Ang II com os receptores AT1.

Embora seja possível que a ECA-2 possa mediar de forma positiva a progressão da DP, pois a mesma é responsável pela formação de Ang 1-7, no presente trabalho a expressão de RNAm para ECA-2 encontra-se reduzida nos animais com DP tratados com enalapril (grupos 1 e 3 ). Provavelmente as vias alternativas mediadas pelas endopeptidases possam estar contribuindo para a formação da Ang 1-7 e assim contrapondo a inflamação causada pela DP. 
Como pode-se observar no presente trabalho, não houve expressão de RNAm para a renina. Esta enzima responsável pela produção de Ang I por meio da clivagem da proteína AGT, advém das células endoteliais presentes nas arteríolas dos tecidos (Lima 2011) ou da circulação sanguínea. Logo é de se esperar que as células que compõe o tecido gengival não expressem tal enzima.

Parece estar claro de que maneira o tratamento com enalapril promoveu proteção contra a perda de volume óssea alveolar em ratos com DP, embora não tenhamos dados neste trabalho que sustente os relatos levantados. Será alvo dos próximos trabalhos a análise da SRA no tecido ósseo além de investigações com relação às citocinas e quimiocinas inflamatórias, além de proteínas presentes nos osteoblastos e osteoclastos as quais modulam o metabolismo ósseo. Em relação às expressões de RNAm torna-se difícil associar nossos resultados pela falta de trabalhos na literatura que abordem o mesmo tema. Sabe-se que o mínimo estimulo causado a um tecido causa aumentos ou diminuições quase que imediatas na expressão dos RNAm. Além disso, a expressão de RNAm é muito lábil, logo o interessante seria estudá-lo nas horas iniciais após a indução da DP e/ou após o início do tratamento farmacológico, pois esta análise aguda da expressão de RNAm para os componentes do SRA poderá ajudar a explicar as condições encontras nos períodos crônicos da DP e tratamento. 
6 Conclusões 



\section{CONCLUSÕES}

O pré-tratamento com inibidor da ECA previne a perda óssea alveolar no modelo de doença periodontal induzida experimentalmente em ratos.

A Reação de cadeia de polimerase quantitativa (PCRq), apresentou no grupo 4 uma maior expressão entre os receptores Mas e Agt, o que pode sugerir uma interação entre tais alvos estudados do SRA. 

REFERÊNCIAS 



\section{REFERÊNCIAS}

Arakawa K. Serine protease angiotensin II systems. J Hypertens Suppl 1996 Dec;14(5):S3-7.

Becari C, Oliveira EB, Salgado MC. Alternative pathways for angiotensin II generation in the cardiovascular system. Braz J Med Biol Res.2011; Sep;44(9):914-9.

Bem-Ari ET, Garrison JC. Regulation of angiotensin mRNA accumulation in rat hepatocytes. Am J Physiol. 1988; 255:E70-9

Berggreen E, Heyeraas KJ. Role of K+ATP channels, endothelin A receptors, and effect of angiotensin II on blood flow in oral tissues. J Dent Res 2003 Jan;82(1):33-7.

Berstein KE, Martin BM, Edwards AS, Berstein EA. Mouse angiotensin-converting enzyme is a protein composed of two homologous domains. J Biol Chem. 1989; 264: 11945-51.

Bezerra, MM; de Lima, V; Alencar, VB; Vieira, IB; Brito, GA; Ribeiro, RA; Rocha,FA. Selective cyclooxygenase-2 inhibition prevents alveolar bone loss in experimental periodontitis in rats. J Periodontol. 2000; 71 (6):1009-14.

Borges Jr I, Moreira EAM, Wilhem Filho D, Oliveira TB, Silva MBS, and Tânia Silvia Fröde, "Proinflammatory and Oxidative Stress Markers in Patients with Periodontal Disease," Mediators of Inflammation, vol. 2007, Article ID 45794, 5 pages, 2007. doi:10.1155/2007/45794

Boucher R, Asselin J, Genest J. A new enzyme leading to the direct formation of angiotensin II. Circ Res 1974;34-35(Suppl 1):203-9.

Burrell LM, Risvanis J, Kubota E et al. Myocardial infarction increases ACE2 expression in rat and humans. Eur Heart J 2005;26:369-75; Discussion 322-4.

Burt B. Position paper: epidemiology of periodontal diseases. J Periodontol. 2005 Aug;76(8):1406-19.

Caldwell PR, Seegal BC, Hsu KC, Das M, Soffer RL. Angiotensin-converting enzyme: vascular endothelial localization. Science. 1976; 191(4231):1050-1.

Campbell DJ, Habener JF. Angiotensinogen gene in expressed and differentially regulated in multiple tissue of the rat. J Clin Invest. 1986; 78:31-9.

Carrasco JLM, Zambrano S, Blanca AJ, Mate A, Vázquez CM. Captopril reduces cardiac inflammatory markers in spontaneously hypertensive rats by inactivation of NF-kB. J of Inflammation 2010, 7:21.

Cassis LA, Saye J, PEACH MJ. Location and regulation of rat angiotensinogen messenger RNA. Hypertension. 1988; 11:591-6 
Chen Z, Tan F, Erdös EG, Deddish PA. Hydrolysis of angiotensin peptides by human angiotensin I-converting enzyme and the resensitization of $\mathrm{B} 2$ kinin receptors. Hypertension. 2005; 46(6):1368-73.

Cornish KG, Joyner WL, Gilmore JP. Evidence for the conversion of angiotensin I to angiotensin II by the coronary microcirculation. Blood vessels 1979;16(5):241-6.

DANSER AH, DEINUM J. Renin, prorenin and the putative (pro)renin receptor. Hypertension, 2005, 46: 1069-1076.

De Cavanagh EMV, Ferder LF, Ferder MD, Stella IY, Toblli JE, Inserra F. Vascular Structure and Oxidative Stress in Salt-Loaded Spontaneously Hypertensive Rats: Effects of Losartan and Atenolol. Am J Hypertension.december 2010. Dez;23(1):21318-25.

de Gasparo M, Catt KJ, Inagami T, Wright JW, Unger T. International Union of Pharmacology. XXIII. The angiotensin II receptors. Pharmacol Rev. 2000; 52(3):41572.

de Gasparo M, Siragy HM. The AT2 receptor: fact, fancy and fantasy. Regul Pept. 1999; 81(1-3):11-24.

Delima AJ, Van Dyke TE. Origin and function of the cellular components in gingival crevice fluid. Periodontol 2003;31:55-76.

De Mello WC. Cardiac intracrine renin angiotensin system. Part of genetic reprogramming? Regul Pept.2006;Jan 15,133(1-3): 10-2.

Ebersole JL. Humoral immune responses in gingival crevice fluid: local and systemic implications. Periodontol 2000 2003;31:135-66.

Erdös EG, Skidgel RA. The unusual substrate specificity and the distribution of human angiotensin I converting enzyme. Hypertension. 1986; 8 (Suppl 1):34-7.

Ferrario CM. Angiotensin-converting enzyme 2 and angiotensin-( 1-7): an evolving story in cardiovascular regulation. Hypertension 2006; 47: 515-21.

Ferreira AJ, Santos RAS. Cardiovascular actions of angiotensin (1-7). Brazilian J of medical and Biological Research 2005; 38:499-507.

Figueiredo CM, Caracterização do sistema renina-angiotensina local no tecido gingival humano sadio e com doença periodontal. Departamento de Ciências Biológicas. Bauru Faculdade de Odontologia de Bauru/ Universidade de São Paulo: $121 \mathrm{p}$

Flemmig TF. Periodontitis. Ann Periodontol 1999 Dec;4(1):32-8.

Fyhrquist F, Saijonmaa O. Minerva Institute for Medical Research and Department of Internal Medicine, Helsinki University Central Hospital; Helsinki, Finland. Reninangiotensin system revisited (Review). J Intern Med 2008; 264: 224-236. 
Garlet GP, Cardoso CR, Silva TA, Ferreira BR, Avila-Campos MJ, Cunha FQ, Silva JS. Cytokine pattern determines the progression of experimental periodontal disease induced by Actinobacillus actinomycetemcomitans through the modulation of MMPs, RANKL, and their physiological inhibitors. Oral Microbiol Immunol. 2006 Feb;21(1):12-20.

Garlet GP, Martins W Jr, Fonseca BA, Ferreira BR, Silva JS. Matrix metalloproteinases, their physiological inhibitors and osteoclast factors are differentially regulated by the cytokine profile in human periodontal disease. $\mathrm{J}$ Clin Periodontol. 2004 Aug;31(8):671-9.

Goodman \& Gilman. Pharmacological basis of therapeutics.2012, 12th Edition editor artmed

Gomez RA, Norling LL, Wilfong N, Isakson P, Lynch KR, Hock R, Quesenberry P.Leukocytes synthesize angiotensinogen. Hypertension 1993 Apr;21(4):470-5.

Gyorfi A, Fazekas A, Suba, Z, Ender F, Rosivall L. Neurogenic component in ligatureinduced periodontitis in the rat. J Clin Periodontol 1994 Oct;21(9):601-5.

Gu SS, Zhang Y, Li XL, Wu Sy, Diao TY, Hai R, Deng HW. Involvement of the skeletal rennin-angiotensin system in age-related osteoporosis of ageing mice. 2012. Biosci Biotechnol. 76(7), 1367-71.

Hagiwara H, Hiruma Y, Inoue A, Yamaguchi A, Hirose S. Deceleration by angiotensin II of the differentiation and bone formation of rat calvarial osteoblastic cells. $J$ Endocrinol 1998 Mar;156(3):543-50.

Hall ER, Kato J, Erdos EG, Robinson CJG, Oshima G. Angiotensin I converting enzyme in the nephron. Life Sci. 1976 ; 18:1299-303.

Hatton R, Stimpel M, Chambers TJ. Angiotensin II is generated from angiotensin I by bone cells ans stimulates osteoclastic bone resorption in vitro. J. Endocrinol 1997. (152):5-10.

Izu Y, Mizoguchi F, Kawamata A, Hayata T, Nakamoto T, Nakashima K et al. (2009). Angiotensin II type 2 receptor blockade increases bone mass. J Biol Chem 284: 4857-4864.

Hall ER, Kato J, Erdös EG, Robinson CJG, Oshima G. Angiotensin I-converting enzyme in the nephron. Life Sci. 1976; 18:1299-303.

Haller H, Lindschau C, Erdmann B, Quass P, Luft FC. Effects of intracellular angiotensin II in vascular smooth muscle cells. Circ Res. 1996; Oct; 79:(4):765-72.

Hirasawa K, Sato Y, Hosoda Y, Yamamoto T, Hanai H. Immunohistochemical localization of angiotensin II receptor and local rennin-angiotensin system in human colonic mucosa. J Histochem Cytochem. 2002; 50(2):275-82. 
Hiruma $\mathrm{Y}$, Inoue A, Hirose $\mathrm{S}$, Hagiwara $\mathrm{H}$. Angiotensin II stimulates the proliferation of osteoblast-rich populations of cells from rat calvariae. Biochem Biophys Res Commun 1997 Jan;230(1):176-8.

Hollenberg NK, Fisher ND, Price DA. Pathways for angiotensin II generation in intact human tissue: evidence from comparative pharmacological interruption of the renin system. Hypertension 1998 Sep;32(3):387-92.

Inagami T, Iwai N, Sasaki K, Yamano Y, Bardhan S, Chaki S et al. Cloning, expression and regulation of angiotensin II receptors. Eur Heart J. 1994; 15 Suppl D:104-7.

Ishikiriama BLC, estudo da expressão e produção de componentes do sistema renina-angiotensina por fibroblastos de gengiva e ligamento periodontal. Departamento de Ciências Biológicas. Bauru Faculdade de Odontologia de Bauru/ Universidade de São Paulo: 155p.

Jackman HL, Massad MG, Sekosan M, Tan F, Brovkovych V, Marcic BM, Erdös EG. Angiotensin 1-9 and 1-7 release in human heart: role of cathepsin A. Hypertension. 2002; 39(5):976-81.

Jackson EK, Garrison JC. Renin and angiotensin. In: Molinoff PB, Ruddon, Goodman \& Gilman's. The pharmacological basis of therapeutics. New York: Mcgraw-Hill, 1995. p.773-58

Jackson TR, Blair AC, Marshall J, Goedert M, Hanley MR. The Mas oncogene encodes an angiotensin receptor. Nature. 1988; 335: 437-40.

Kaneko $\mathrm{K}$, Ito $\mathrm{M}$, Fumoto $\mathrm{T}$, Fukuhara $\mathrm{R}$, Ishida J, Fukamizu A, Ikeda $\mathrm{K}$. Physiological function of the angiotensin AT1a receptor in bone remodeling. J. Of bone and mineral research 2011,26; 2959-66.

Kokkonen JO, Lindstedt KA, Kovanen PT. Role for chymase in heart failure: angiotensin II-dependent or -independent mechanisms? Circulation 2003; 107: 25224.

Kramkowski K, Mogielnicki A, Buczko W. The physiological significance of the alternative pathways of angiotensin II production. 2006; 57(4):529-39.

Lam SY, Leung OS. A locally generated angiotensin system in rat carotid body. Regul Pept 2002; 107: 97-103.

Lamparter S, Kling L, Schrader M, Ziegler R, Pfeilschifter J. Effects of angiotensin II on bone cells in vitro. J Cell Physiol 1998 Apr;175(1):89-98.

Lapteva N, Nieda M, Ando Y, Ide K, Hatta-Ohashi Y, Dymshits G, Ishikawa Y, Juji T, Tokunaga $\mathrm{K}$. Expression of renin-angiotensin system genes in immature and mature dendritic cells identified using human cDNA microarray. Biochem Biophys Res Commun. 2001 Jul 27;285(4):1059-65. 
Lavoie JL, SIGMUND CD, Minireview: Overview of the Renin-Angiotensin SystemAn Endocrine and Paracrine System Endocrinology, 2003. 144: 2179-2183.

Le Trong $\mathrm{H}$, Neurath $\mathrm{H}$, Woodbury RG. Substrate specificity of the chymotrypsin-like protease in secretory granules isolated from rat mast cells. Proc Natl Acad Sci U S A 1987 Jan;84(2):364-7.

Leung PS, The peptide hormone angiotensin Il:its new functions in tissue and organs. Curr Protein Pept Sci. 2004; 5(4):267-73.

Linderman JR, Greene AS. Distribution of angiotensin II receptor expression in the microcirculation of striated muscle. Microcirculation. 2001; 8(4):275-81.

Lima MC (2011). O sistema renina-angiotensina da doença periodontal induzida experimentalmente em ratos. Departamento de Ciências Biológicas. Bauru Faculdade de Odontologia de Bauru/ Universidade de São Paulo: 113p.

Listgarten MA. Nature of periodontal diseases: pathogenic mechanisms. J Periodontal Res 1987 May;22(3):172-8.

Lohinai Z, Benedek P, Feher E, Gyorfi A, Rosivall L, Fazekas A, Salzman AL, Szabo C. Protective effects of mercaptoethylguanidine, a selective inhibitor of inducible nitric oxide synthase, in ligature-induced periodontitis in the rat. Brit $J$ Pharmacol 1998 Feb;123(3):353-60.

Lundergan WP, Ferry D, Kobayashi H, Snowdowne KW. Angiotensin-II increases cytoplasmic calcium, cell number and total DNA for human periodontal ligamental cells in vitro. J Periodontal Res 1999 May;34(4):223-8.

Madden TE, Caton JG. Animal models for periodontal disease. Methods Enzymol 1994;253:106-19.

Marchesi C, Paradis P, Schiffrin EL. Role of the renin-angiotensin system in vascular inflammation. Trends in Pharmacological Sciences. 2008: 29(7): 367-74.

Marcic B, Deddish PA, Jackman HL, Erdös EG. Enhancement of bradykinin and resensitization of its B2 receptor. Hypertension. 1999; 33(3):835-43.

Maruta $\mathrm{H}$, Arakawa K. Confirmation of direct angiotensin formation by kallikrein. Biochem J 1983 Jul;213(1):193-200.

Kaneko K, Ito $\mathrm{M}$, Fumoto $\mathrm{T}$, Fukuhara $\mathrm{R}$, Ishida J, Fukamizu A, Ikeda K. Physiological function of the angiotensin AT1a receptor in boné remodeling, Journal of bone and mineral research, Dec 2011; Vol 26 numero 12 ; 2959-2966

NGUGEN G, DANSER AH.Prorenin and pro(renin) receptor: A review of avaliable data from in vitro studies and experimental models in rodents. Exp Physiol, 2008, 93:557-563. 
Nickenig G, Geisen G, Vetter $H$, Sachinidis A. Characterization of angiotensin receptors on human skin fibroblasts. J Mol Med 1997 Mar;75(3):217-22.

Nishan S. Kalupahana, Florence Massiera, Annie Quignard-Boulange, Gérard Ailhaud, Brynn H. Voy. Overproduction of Angiotensinogen from Adipose Tissue Induces Adipose Inflammation, Glucose Intolerance, and Insulin Resistance David H. Wasserman and Naima Moustaid-Moussa, Adipocyte Biology Obesity (2012) 20, 48-56).

Ohuchi N, Koike K, Sano M, Kusama T, Kizawa Y, Hayashi K, Taniguchi Y, Ohsawa M, Iwamoto K, Murakami H. Proliferative effects of angiotensin II and endothelin-1 on guinea pig gingival fibroblast cells in culture. Comp Biochem Physiol C Toxicol Pharmacol 2002 Aug;132(4):451-60.

Ohuchi N, Hayashi K, Koike K, Kizawa Y, Kusama T, Ohsawa M, Taniguchi Y, Iwamoto K, Sano M, Murakami H. Pharmacological properties of angiotensin II receptors in cultured rabbit gingival fibroblasts. Comp Biochem Physiol C Toxicol Pharmacol 2004 Mar;137(3):281-9.

Okunishi H, Miyazaki M, Okamura T, Toda N. Different distribution of two types of angiotensin II-generating enzymes in the aortic wall. Biochem Biophys Res Commun 1987 Dec;149(3):1186-92.

Okunishi $\mathrm{H}$, Miyazaki M, Toda $\mathrm{N}$. Evidence for a putatively new angiotensin Ilgenerating enzyme in the vascular wall. J Hypertens 1984 Jun;2(3):277-84.

Oliveira MA, Fortes ZB, Santos RA, Kosla MC, De Carvalho MH. Synergistic effect of angiotensin (1-7) on bradykinin arteriolar dilation in vivo. Peptides. 1999; 20(10):1195-201.

Oliveira TM, Fator de crescimento endotelial vascular na doença periodontal inflamatória induzida experimentalmente em ratos. Departamento de Ciências Biológicas. Bauru Faculdade de Odontologia de Bauru/ Universidade de São Paulo: $143 p$.

Oliver RC, Brown LJ, Loe H. Periodontal diseases in the United States population. J Periodontol. 1998 Feb;69(2):269-78.

Oliveira TM, Sakai VT, Machado MAAM, Dionísio TJ, Cestari TM, Taga R, Amaral SL, Santos CF. COX-2 inhibition decreases VEGF expression and the alveolar bone loss during the progression of experimental periodontitis in rats. $J$

Periodontol 2008 June;79(6):1062-9.

Owen CA, Campbell EJ. Angiotensin II generation at the cell surface of activated neutrophils: novel cathepsin G-mediated catalytic activity that is resistant to inhibition. J Immunol 1998 Feb;160(3):1436-43.

Page RC. The role of inflammatory mediators in the pathogenesis of periodontal disease. J Periodontal Res 1991 May;26(3 Pt 2):230-42. 
Paul M, Mehr AP, Kreutz, R. Physiology of local renin-angiotensin systems. Physiol Rev. 2006; 86:747-803.

Paula CA, Sousa MV, Salgado MC, Oliveira EB. Purification and substrate specificity of an angiotensin converting elastase-2 from the rat mesenteric arterial bed perfusate. Biochim Biophys Acta 1998 Oct;1388(1):227-38.

Peach MJ. Renin-angiotensin system: biochemistry and mechanisms of action. Physiol Rev 1977 Apr;57(2):313-70.

Pérez-Castrillón JL, Silva J, Justo I, Sanz A, Luquero MM, Igea M, Escudero P, Pueyo C, Díaz C, Hernández G, Duenas A. The American Journal of Hypertension. 2003; 16: 453-459.

Phillips MI, Kagiyama S: Angiotensin II as a pro-inflammatory mediator. Curr Opin Investig Drugs 2002; 3:569-577.

Piqueras L, Kubes P, Alvarez A, OConnor E, Issekutz AC, Esplugues JV et al. Angiotensin II induces leucyte-endothelial cell interactions in vivo via AT1 and AT2 receptor-mediated P-selectin upregulation. Circulation 2000. 102: 2118-2128.

Raizada MK, Ferreira AJ. ACE2: a new target for cardiovascular disease therapeutics. J Cardiovasc Pharmacol. 2007; 50(2):112-9.

Rajkumar DSR, Faitelson A V, Gudyrev OS, Dubrovin GM, Pokrovski MV, Ivanov AV. Comparative evaluation of enalapril and losartan in pharmacological correction of experimental osteoporosis and fractures of its background. J of Osteoporosis 2013;

Re RN, Cook JL. The intracrine Hypothensis: an uptdate. Regul Pept. 2006; Jan 15;133: (1-3):1-9.

Rodini CO, Batista AC, Dionísio TJ, Santos CF, Cunha FQ, Lara VS. Morphologic evaluation and expression of matrix metalloproteinases-2 and 9 and nitric oxide during experimental periodontal disease in rat. J Mol Histol. 2008 Jun;39(3):27582.

Ryan JW, Ryan US, Schultz DR, Whitaker C, Chung A, Dorer FE. Subcellular localization of pulmonary angiotensin-corventin enzyme (kininase II). Biochem J. $1975 ; 146: 497-9$

Ryan JW, Day AR, Schultz DR, Ryan US, Chung A, Marlborough DI, et al. Localization of angiotensin-corventin enzyme (kininase II). Preparation of antibodyhemeoctapeptide conjugates. Tissue Cell. 1976; 8:111-24.

Santos RA, Ferreira AJ. Angiotensin-(1-7) and the renin-angiotensin system. Curr Opin Nephrol Hypertens 2007; 16: 122-8.

Santos RAS, Brosnihan KB, Chappell MC, Pesquero JL, Chernicky CL, Greene LJ, et al. Converting enzyme activity and angiotensin metabolism in the dog brainstem. Hypertension. 1988; 11:153-7. 
Santos CF, Akashi AE, Dionísio TJ, Didier DN, Greene AS, Oliveira SHP, Pereira HJ, Becari C, Oliveira EB, Salgado MCO. Characterization of a local reninangiotensin system in rat gingival tissue. J Periodontol 2009 Jan;80(1):130-9.

Santos CF, Caprio MA, Oliveira EB, Salgado MC, Schippers DN, Munzenmaier DH, Greene AS. Functional role, cellular source and tissue distribution of rat elastase-2, an angiotensin Il-forming enzyme. Am J Physiol Heart Circ Physiol 2003 Aug;285(2):H775-83.

Santos CF, Greene AS, Salgado MC, Oliveira EB. Conversion of renin substrate tetradecapeptide to angiotensin II by rat MAB elastase-2. Can J Physiol Pharmacol 2004 Nov;82(11):1000-5.

Santos CF, Oliveira EB, Salgado MC, Greene AS. Molecular cloning and sequencing of the cDNA for rat mesenteric arterial bed elastase-2, an angiotensin II-forming enzyme. J Cardiovasc Pharmacol 2002b May;39(5):628-35.

Santos CF, Paula CA, Salgado MCO, Oliveira EB. Kinetic characterization and inhibition of the rat MAB elastase-2, an angiotensin I-converting serine protease. Can J Physiol Pharmacol 2002a Jan;80(1):42-7.

Santos RA, Castro $\mathrm{CH}$, Gava E et al. Impairment of in vitro and in vivo heart function in angiotensin-(1-7) receptor MAS knockout mice. Hypertension 2006; 47: 996-1002.

Segawa M, Nakao S, Ogata Y, Sugiya H, Furuyama S. Angiotensin II induces prostaglandin $\mathrm{E}(2)$ release in human gingival fibroblasts. Life Sci 2003 Jan;72(7):795-803.

Schiavone MT, Santos RA, Brosnihan KB, Khosla MC, Ferrario CM. Release of vasopressin from the rat hypothalamo neurohypophysial system by angiotensin-(1-7) heptapeptide. Proc Natl Acad Sci USA 1988; 85: 4095-8.

Schiffrin, E.L. (2002) Beyond blood pressure: the endothelium and atherosclerosis progression. Am. J. Hypertens. 15, 115S-122S.

Schulz W W, Hagler HK , Buja LM, Erdös EG. Ultrastructural localization of angiotensin I-converting enzyme (EC 3.4.15.1) and neutral metalloendopeptidase (EC 3.4.24.11) in the proximal tubule of the human kidney. Lab Invest. 1988; 59(6):789-97.

Shimizu H, Nakagami H, Osako M K, Hanayama R, Kunugiza Y, Kizawa T, Tomida T, Yoshikawa H, Ogihara T, Morishita R. Angiotensin II accelerates osteoporosis by activating osteoclastos. The FASEB Journal. 2008, 22: 2465-75.

Soubrier F, Alheng-Gelas F, Hubert C, AllegriniJ, John M, tregear G, et al. Two putative active centers in humamangiotensin I-converting enzyme revealed by molecular cloning. Proc Natl Acad Sci USA. 1988; 85: 9386-90

Souza PPC, Fukada SY, Cunha FQ, Costa CAS, Costa-Neto CM. Regulation of 
angiotensin II receptors levels during rat induced pulpitis. Regul Pept. 2007; 140:27-31.

Speth RC, Thompson SM, Johns SJ. Angiotensin II receptors. Structural and functional considerations. Adv Exp Med Biol. 1995; 377:169-92.

Snyder RA, Wintroub BU. Inhibition of angiotensin-converting enzyme by des-Leu10angiotensin I: a potential mechanism of endogenous angiotensin-converting enzyme regulation. Biochim Biophys Acta. 1986; 871(1):1-5.

Sukumaran V, Veeraveedu PT, Gurusamy N, Yamaguchi K, Lakshmanan AP, Ma M et al. Cardioprotective effects of telmisartan against heart failure in rats induced by experimental autoimmune myocarditis through the modulation of angiotensinconverting enzyme-2/angiotensin 1-7/mas receptor axis. 2001. Inst J Biol Sci 7:10771092.

Suzuki Y, Ruiz-Ortega M, Lorenzo O, Ruperez M, Esteban V, Egido J. Inflammation and angiotensin II. Int J Biochem Cell Biol 2003 Jun;35(6):881-900.

Takai S, Jin D, Muramatsu M, Miyazaki M. Chymase as a novel target for the prevention of vascular diseases. Trends Pharmacol Sci 2004; 25: 518-22.

Takai S, Shiota N, Yamamoto D, Okunishi H, Miyazaki M. Purification and characterization of angiotensin II-generating chymase from hamster cheek pouch. Life Sci 1996;58(7):591-7.

THAM DM, Martin-McNulty B, Wang YX, et al: Angiotensin II is associated with activation of NF-kappaB-mediated genes and downregulation of PPARs. Physiol Genomics 2002; 11:21-30

Tonnesen MG, Klempner MS, Austen KF, Wintroub BU. Identification of a human neutrophil angiotensin II-generating protease as cathepsin G. J Clin Invest. 1982; 69:25-30.

Trask AJ, Ferrario CM. Angiotensin 1-7: Pharmacology and new perspectives in cardiovascular treatments. Cardio Vasc Reviews. 2007; 25 (2):162-74.

Urata $\mathrm{H}$, Kinoshita A, Misono KS, Bumpus FM, Husain A. Identification of a highly specific chymase as the major angiotensin II-forming enzyme in the human heart. $J$ Biol Chem 1990 Dec;265(36):22348-57.

Urata $\mathrm{H}$, Nishimura $\mathrm{H}$, Ganten D. Mechanisms of angiotensin II formation in humans. Eur Heart J 1995 Dec;16 Suppl N:79-85.

Van Dyke TE, Serhan CN. Resolution of inflammation: a new paradigm for the pathogenesis of periodontal diseases. J Dent Res 2003 Feb;82(2):82-90.

Wang L, Hu X, Zhang W, Tian F. Angiotensin (1-7) ameliorates angiotensin II induced inflammation by inhibiting LOX-1 expression. Inflamm. Res 2013, 65:219-28. 
Watanabe T, Barker TA, Berk BC. Angiotensin II and the endothelium: diverse signals and effects. Hypertension 2005; 45: 163-9.

Weinberg, MA; Bral, M. Laboratory animal models in periodontology. J Clin Periodontol. 1999; 26 (6):335-40.

Wilson M. Biological activities of lipopolysaccharides from oral bacteria and their relevance to the pathogenesis of chronic periodontitis. Sci Prog 1995;78(Pt 1):1934.

Wright JW, Yamamoto BJ, Harding JW. Angiotensin receptor subtype mediated physiologies and behaviors: New discoveries and clinical targets. Prog Neurobiol. 2008; 84(2):157-81. 
Anexo 



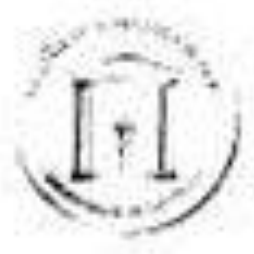

\section{Universidade de São Paulo Faculdade de Odontologia de Bauru}

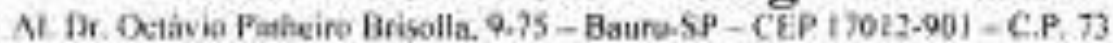
PABX $(0 \times X 14) 3235-3000-\mathrm{FAX}(0 \times \times 14) 3221-4679$

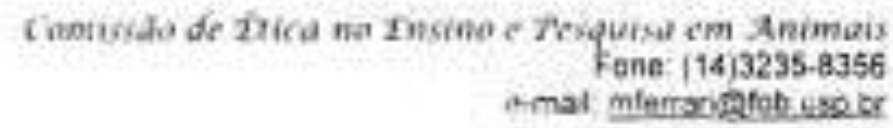

CEEPA-ProC. ND OI3/2OII

Bavru, 28 de junho de 2011

Senher Prafesser.

O propate de pesquisa encaminhado a esta comissäa de Ctica no tnsino e Pesquisa em Animad, donominado Eleitos da inibigsto da enzims conversora de Angiotensina sobre a doenca periodontal indusida experimentalmente em ratos, de autoria do Fubens Pinenta Maciel, for enviado ao relator para avaliaça e cansiderado APROVADO em reunibo desta Comistao realizada so dia 21 de junho de 2011.

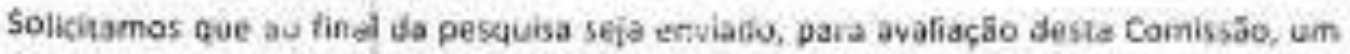
Relatónia com os resulados obtidos para andise tica e emissio de parecer. Final a qual podera set utivizado para fins de publiceşab cientifica.

Atbociosamente.

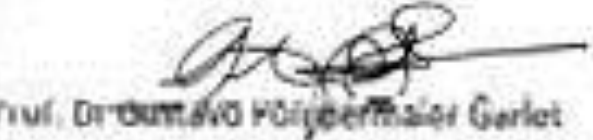

Presiocrte da Comiss\$̃o de Etica ro Ensino e Pesquisa em Animais

Prof. Dr. Carlos ferreira dos Santos

Docente do Departamento de Ciércias Biolegieas 